\title{
Sandstone-Shale Geochemistry of Miocene Surma Group in Bandarban Anticline, SE Bangladesh: Implications for Provenance, Weathering, and Tectonic Setting
}

\author{
Md. Masidul Haque*, Mrinal Kanti Roy \\ Department of Geology and Mining, University of Rajshahi, Rajshahi, Bangladesh
}

Email address:

md_hq@ru.ac.bd (Md. M. Haque)

${ }^{*}$ Corresponding author

\section{To cite this article:}

Md. Masidul Haque, Mrinal Kanti Roy. Sandstone-Shale Geochemistry of Miocene Surma Group in Bandarban Anticline, SE Bangladesh: Implications for Provenance, Weathering, and Tectonic Setting. Earth Sciences. Vol. 9, No. 1, 2019, pp. 38-51.

doi: $10.11648 /$ j.earth.20200901.15

Received: October 27, 2019; Accepted: November 23, 2019; Published: February 14, 2020

\begin{abstract}
The present study analyzes the geochemical composition of sandstone and shale of the Miocene Surma Group to decipher the provenance, tectonic settings and paleoweathering condition of source area in the Bandarban Anticline which is at the western margin of Indo-Burmese Hill Ranges. Statistical empirical index of chemical weathering of the sediments that have been extracted by the Principal Component Analysis (PCA) is used to understand the weathering profile of the sediments of the study area. The PCA of the geochemical composition yields three principal components (PC-1, PC-2, and PC-3), which capture total variance $52.83 \%, 17.58 \%$ and $6.94 \%$, respectively. The $\mathrm{PC}-1$ shows the loss of $\mathrm{SiO}_{2}$ during weathering of preexisting source rocks; $\mathrm{PC}-2$ reveals the enrichment of $\mathrm{Na}_{2} \mathrm{O}, \mathrm{CaO}$, and $\mathrm{P}_{2} \mathrm{O}_{5}$ due to leeching and carried by groundwater during weathering; highest loadings with $\mathrm{MnO}$ and $\mathrm{Cr}$ shows in $\mathrm{PC}-3$ due to redox environment during early diagenetic of marine sediments. The MFW and A-CN-K diagrams show an intense weathering trend, and backward trend of the MFW diagram and the major elements provenance discriminant diagram refers to the mature polycyclic quartzes provenance and originated dominantly from felsic to intermediate igneous rocks. The trend of the $\mathrm{SiO}_{2} / \mathrm{Al}_{2} \mathrm{O}_{3}-\mathrm{Na}_{2} \mathrm{O} / \mathrm{K}_{2} \mathrm{O}$ shows the hydraulic sorting effect and sediments were originated primarily from a recycled sedimentary provenance. The CIA (67.68-80.89), ICV (0.60-1.29, avg. 0.83$)$ and $\mathrm{K}_{2} \mathrm{O} / \mathrm{Na}_{2} \mathrm{O}$ ratios show a moderate to high maturity of the sediments and is derived from both weak and intensively weathered source rocks. Discriminate diagrams related to tectonic provenance refer to the deposit of the sediment dominantly under the influence of collision (active continental collision, compression) and mature sediment derived to the depositional basin after upliftment of the source areas after that collision.
\end{abstract}

Keyword: Geochemistry, Provenances, Weathering, Tectonic Settings, Miocene Surma Group

\section{Introduction}

This work represents mainly the geochemistry of the exposed sandstones and shales of Surma Group from the Bandarban Anticlines, Chittagong Hill Tracts which lies in the Southeastern part of Bangladesh (Figure 1). The geochemical composition of clastic sedimentary rocks is controlled by various factors including parent rock composition, weathering process, climatic condition during weathering, transportation mechanisms, depositional environment of the basin and post-depositional processes [13]. Hence, the geochemistry of clastic sediments represents the provenance, chemical weathering, hydraulic sorting, abrasion of the sediment and numerous investigations are substantiating the above aspects pertaining to genesis of both ancient and modern siliciclastic sediments [4-13].

Geochemical signatures of siliciclastic rocks have been used to identification of palaeotectonic settings of provenances [7, 11, 14-17]. Shale sediment contains most of the mineral constituents of the parents' rock and represents the characteristic of the crustal composition of the provenance much better than any other terrigenous sedimentary rocks [18]. The original signature of the provenance and palaeo-weathering conditions of the 
depositional basin is preserved well in the bulk chemistry of shale [19]. However, the monitor of the decomposition of the unstable mineral includes the Chemical Index of Weathering (CIW) and the Chemical Index of Alteration (CIA) [5, 20]. The CIA index predicts the conversion of feldspar mineral that is the most abundant rock-forming mineral in the earth's crust have widely used in past studies [11, 21]. Other weathering indices like $\mathrm{Al}_{2} \mathrm{O}_{3} / \mathrm{Fe}_{2} \mathrm{O}_{3}, \quad \mathrm{SiO}_{2} / \mathrm{Fe}_{2} \mathrm{O}_{3}$, $\mathrm{SiO}_{2} / \mathrm{Al}_{2} \mathrm{O}_{3}$, and $\mathrm{K}_{2} \mathrm{O} / \mathrm{Al}_{2} \mathrm{O}_{3}$ ratio; Index of compositional variability (ICV) and $\mathrm{Al}_{2} \mathrm{O}_{3}-\left(\mathrm{CaO}+\mathrm{Na}_{2} \mathrm{O}\right)-\mathrm{K}_{2} \mathrm{O}(\mathrm{A}-\mathrm{CN}-\mathrm{K})$ ternary plots are widely used to interpret maturity and provenance of the rocks $[5,22]$.

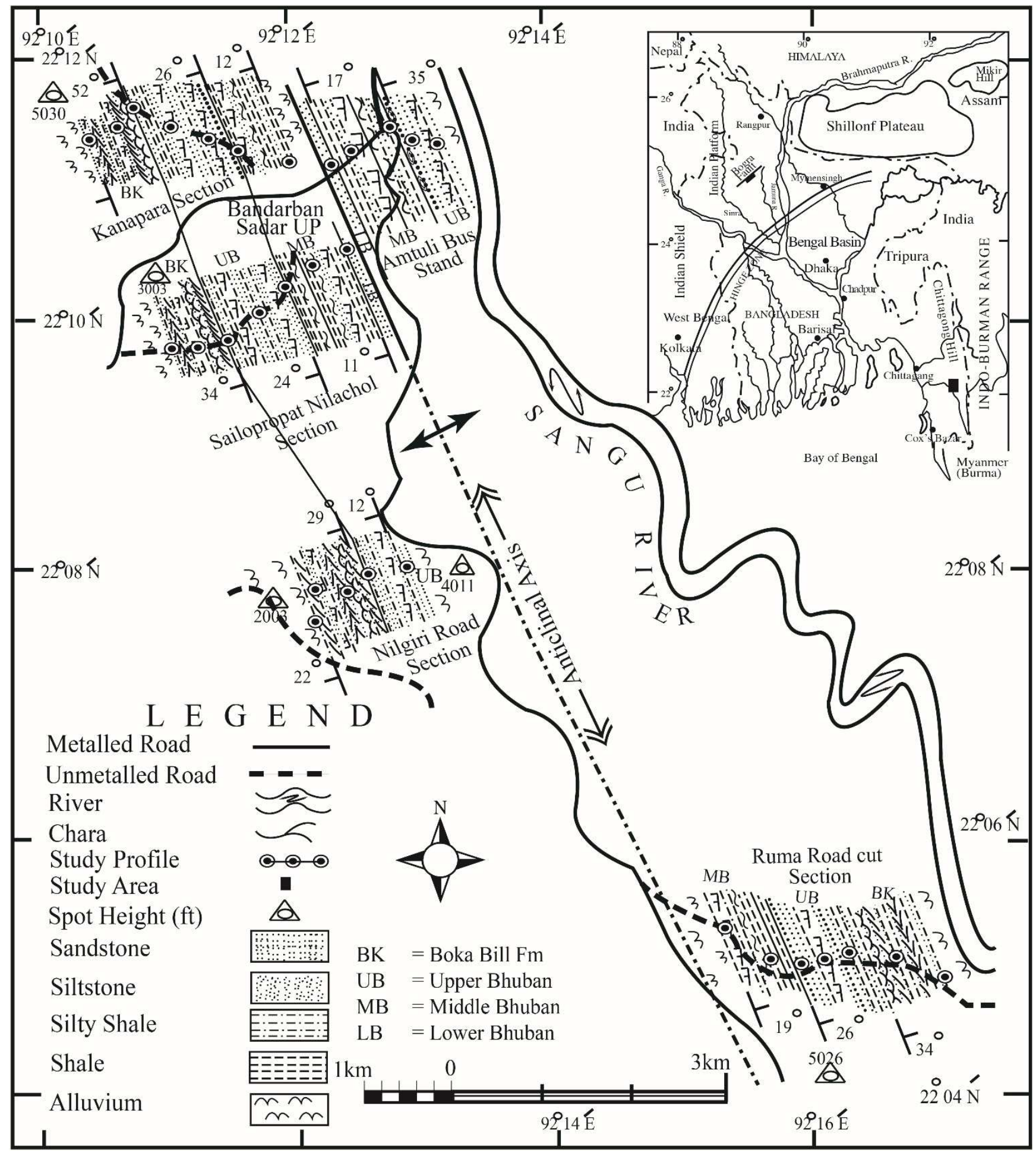

Figure 1. Geological and tectonic map of study areas showing lithofacies and sample locations [33].

Several studies have been made in relation to the regional geology, sedimentology and tectonic evolution of the
Miocene sediments of the Surma Basin as well as the southeastern part of the Bengal Basin. In these studies, have 
used some traditional diagrams and statistical analysis to interpret the geochemical data. Geochemical analysis interprets Neogene sediments as the sediments are rich in quartz, sedimentary and metamorphic lithic fragments which indicating a recycled orogen source and have deposited in an active or passive continental margin setting and form from felsic source rocks [23-27] in these studies. Using the CIA, CIW, ICV, PIA values and the ratio of $\mathrm{SiO}_{2} / \mathrm{Al}_{2} \mathrm{O}_{3}$ in these studies interpret the sediments have low degrees of chemical weathering in the source areas as well as immature to moderately mature in nature [23, 27] and the potential sedimentary source supply of Himalayan detritus through Ganga-Brahmaputra river system [25, 26, 28].

The purpose of the study is to analyzes chemical weathering that is extracted by principal component analysis (PCA), using MFW diagram for interpret source-area weathering, $\mathrm{SiO}_{2} / \mathrm{Al}_{2} \mathrm{O}_{3}-\mathrm{Na}_{2} \mathrm{O} / \mathrm{K}_{2} \mathrm{O}$ diagram for understand the hydraulic sorting processes [29, 30], discriminantfunction multi-dimensional diagram for interpret tectonic settings (in terms of plate tectonics) of Miocene sediment of Bandarban Anticline and compare with traditional geochemical model [16, 31, 32, 6-8].

\section{Geology}

The initiation of the Bengal basin of Bangladesh and part of eastern India (West Bengal) occurred during the Gondwana continental landmass fragmentation at the late Mesozoic (ca. $\sim 125 \mathrm{Ma}$ ) [34]. The collision of the Subsequent Indian and Eurasian Plates at $\sim 55-50$ Ma resulting in the formation of Himalaya $(\sim 27-17 \mathrm{Ma})$ is providing the major sediment to the Bay of Bengal [28, 35-37]. The sedimentary characters show the major deltaic influence since the Oligocene. The collision between the Indian and Burmese plates resulted in the formation of Indo-Burmese ranges during the EoceneOligocene (and the folding of the outer part of the western part of this range occur within the last few million years (ca. $\sim 0.4-2.9 \mathrm{Ma}$ ) [38-41]. Sediments within the Bengal basin have compressed and uplifted to form of Chittagong-Tripura Fold Belt (CTFB) which is on the western side of this ranges (Figure 1). The sediment of the Bengal Basin is carried out by the easterly palaeo-Brahmaputra river and westerly palaeo Ganges river system. Two variable fluvial system sediment is the main sources of the late Miocene shelf, which are similar depositional processes to the modern-day shelf that having high sediment loads and variable seasonal discharges (Figure 1). The early to middle Miocene Bhuban Formation and the middle to late Miocene Boka Bil Formation comprise the sediments the study areas. These thick accumulations of sandstones and mudstone were deposited during repeated transgression-regression and derived from neighboring orogenic belts $[33,42,43]$. The Neogene Surma Group sediments deposited in the deeper part of the basin and a thickness reached about $\geq 4 \mathrm{~km}$ in the eastern fold belts [44]. Hence the lithology and their sedimentary structures are the basis established stratigraphy of that region. The rock sequence of the study areas is mainly composed of fine to medium-grained sandstone, silty shale, shale, sandy siltstone, siltstone, conglomerate, etc. [33, 45, 46]. The stratigraphic succession of the area is shown in Figure 2.

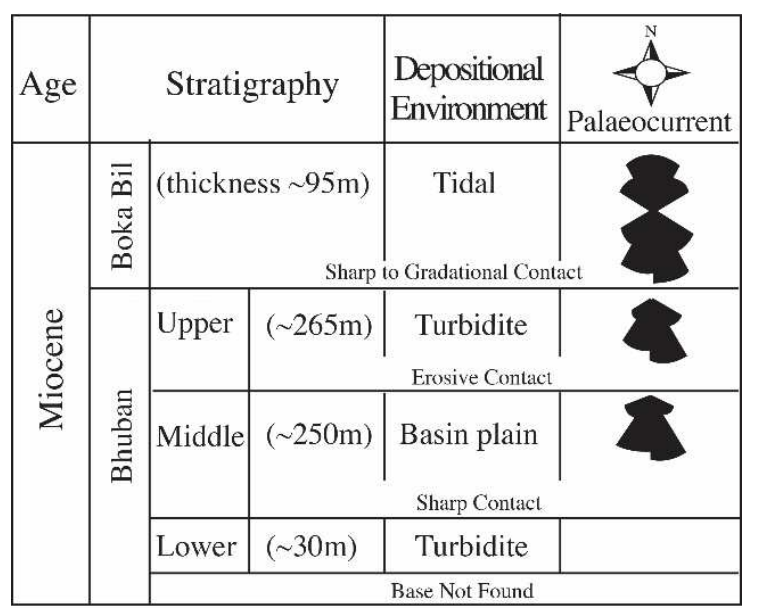

Figure 2. Stratigraphic succession of the study area of the Bandarban anticline (Compile form of 33, 42, 47).

\section{Methodology}

The samples of Miocene Surma Group of sediments in Bandarban anticline were collected from the exposed rock section of this area. Twenty sandstone and shale crushed samples (10 each) have been used to determine the major elements (in percentage) and some minor elements (in ppm) composition using by the XRF technique on fused beads [48]. Analyses were carried out with an X-ray Fluorescence (XRF) model ZSX Primus, Rigaku with standard curves based on International Rock Standards at the laboratory of the Institute of Mining, Mineralogy and Metallurgy IMMM, Joypurhat, Bangladesh. Relative errors on major elements were determined by heating the dried samples to $950^{\circ} \mathrm{C}$ for 2 hours and it usually comes at $<2 \%$ and causes Loss on Ignition (LOI). $\mathrm{Cu}, \mathrm{Zn}, \mathrm{Ni}$, and $\mathrm{Cr}$ elements were measured by Atomic absorption spectroscopy (AAS) Model AA240, Agilent at IMMM to correlate with XRF measure. In this study, statistical empirical index of chemical weathering extracts by PCA is carried out to recognize the structure of the data. Discriminant Function diagrams have been used to characterize the sedimentary and tectonic provenance of the sediments $[6,8,31]$. The MFW diagrams, $\mathrm{SiO}_{2} / \mathrm{Al}_{2} \mathrm{O}_{3}-$ $\mathrm{Na}_{2} \mathrm{O} / \mathrm{K}_{2} \mathrm{O}$ diagrams, $\mathrm{A}-\mathrm{CN}-\mathrm{K}$ diagrams, and CIW, CIA, and ICV values were utilized to quantify the effects of source weathering, climatic condition, sediment maturity, and hydraulic sorting processes [5, 6, 20, 22, 29, 30].

In this study, $\mathrm{CO}_{2}$ data was not quantified. $\mathrm{CaO}$ derived from carbonate was corrected using the method of [11] and [49]. The content of $\mathrm{CaO}$ was corrected for apatite using $\mathrm{P}_{2} \mathrm{O}_{5}\left(\mathrm{CaO}^{*}=\mathrm{CaO}-10 / 3 \cdot \mathrm{P}_{2} \mathrm{O}_{5}\right)$. Based on that, if the corrected $\mathrm{CaO}^{*}$ value is lower than the amount of $\mathrm{Na}_{2} \mathrm{O}$, this corrected $\mathrm{CaO}^{*}$ value is adopted. On the other hand, if the $\mathrm{CaO}^{*}$ value is higher than the amount of $\mathrm{Na}_{2} \mathrm{O}$, it is assumed that the correction of $\mathrm{CaO}$ value is equal to the amount of $\mathrm{Na}_{2} \mathrm{O}$. 


\section{Results}

\subsection{Geochemistry of Sandstone and Shale}

The major element composition of the samples show high concentration of $\mathrm{SiO}_{2}$ (53.60-77.40\%), moderately high concentration of $\mathrm{Al}_{2} \mathrm{O}_{3}$ (8.44-21.9\%), $\mathrm{Fe}_{2} \mathrm{O}_{3}$ (4.17-7.55\%) and $\mathrm{K}_{2} \mathrm{O}(2.21-4.5 \%)$ and low concentration of $\mathrm{MgO}(0.86-$ $3.16 \%), \mathrm{CaO}(0.34-9.96 \%), \mathrm{Na}_{2} \mathrm{O}(0.50-1.69 \%), \mathrm{TiO}_{2}(0.37-$ $0.88 \%), \mathrm{P}_{2} \mathrm{O}_{5}(0.09-0.25 \%)$ and $\mathrm{MnO}(0.05-0.28 \%)$ (Table 1). The sandstones contain more $\mathrm{SiO}_{2}$ than those of the shales, but the concentrations of other major elements are higher in shales, which reflect their association with claysized phases [50]. The sandstones and shales were also compared to UCC (Upper Continental Crust) and PAAS (Post-Archaean Australian Shale) as shown in Figure 3 [21, 51]. The average concentration of $\mathrm{SiO}_{2}$ (1.05), $\mathrm{Al}_{2} \mathrm{O}_{3}$ (0.95), $\mathrm{TiO}_{2}(0.86), \mathrm{Fe}_{2} \mathrm{O}_{3}(1.01), \mathrm{MnO}(0.70), \mathrm{K}_{2} \mathrm{O}(1.12)$ and $\mathrm{P}_{2} \mathrm{O}_{5}$ (1.67) in these samples are highly comparable those of with the UCC, whereas the average concentration of $\mathrm{CaO}(0.21)$, $\mathrm{Na}_{2} \mathrm{O}(0.31)$ and $\mathrm{MgO}(0.57)$ are low comparable (Figure 3). Contents of $\mathrm{K}_{2} \mathrm{O}$ and $\mathrm{Na}_{2} \mathrm{O}$ and their ratios $\left(\mathrm{K}_{2} \mathrm{O} / \mathrm{Na}_{2} \mathrm{O}>1\right)$ signify that $\mathrm{K}$-feldspar dominantly source rocks and enrichment of $\mathrm{K}_{2} \mathrm{O}$ is associated with the Illite clay mineral in shales and sandstones. In comparison with UCC, the shale samples are low in $\mathrm{CaO}, \mathrm{Na}_{2} \mathrm{O}$ and, high in $\mathrm{TiO}_{2}, \mathrm{~K}_{2} \mathrm{O}$, and $\mathrm{Al}_{2} \mathrm{O}_{3}$. The abundance of $\mathrm{Al}_{2} \mathrm{O}_{3}$ is used to make comparisons amongst different lithologies as $\mathrm{Al}_{2} \mathrm{O}_{3}$ shows its immobile nature during weathering, diagenesis, and metamorphism [52]. Enrichment in $\mathrm{Al}_{2} \mathrm{O}_{3}$ and $\mathrm{TiO}_{2}$ indicates that the $\mathrm{Al}$ and $\mathrm{Ti}$ are easily absorbed by clays and are concentrated in the finer, more weathered materials [53]. The average concentrations of $\mathrm{SiO}_{2}$ (1.01), $\mathrm{Al}_{2} \mathrm{O}_{3}$ (0.93), $\mathrm{TiO}_{2}$ (0.90), $\mathrm{Fe}_{2} \mathrm{O}_{3}$ (1.00), $\mathrm{MnO}$ (1.00), $\mathrm{CaO}$ (1.22), $\mathrm{Na}_{2} \mathrm{O}$ (1.29), $\mathrm{K}_{2} \mathrm{O}$ (0.93), $\mathrm{MgO}(1.24)$ and $\mathrm{P}_{2} \mathrm{O}_{5}(0.86)$ are comparable with the PAAS (Figure 3).

The behavior of most of the major oxides (e.g. $\mathrm{MgO}$,
$\mathrm{Fe}_{2} \mathrm{O}_{3}{ }^{*}, \mathrm{TiO}_{2}, \mathrm{CaO}$, and $\mathrm{Al}_{2} \mathrm{O}_{3}$ ) shows a negative correlation with $\mathrm{SiO}_{2}$. The negative correlation between $\mathrm{SiO}_{2}$ and $\mathrm{Al}_{2} \mathrm{O}_{3}$ $\left(\mathrm{r}=-0.458, \mathrm{n}=20\right.$; Table 2) indicates that most of the $\mathrm{SiO}_{2}$ is present as quartz grains [54, 55]. However, the positive correlation of $\mathrm{K}_{2} \mathrm{O}, \mathrm{TiO}_{2}, \mathrm{MgO}, \mathrm{Fe}_{2} \mathrm{O}_{3}{ }^{*}$ and $\mathrm{P}_{2} \mathrm{O}_{5}$ with $\mathrm{Al}_{2} \mathrm{O}_{3}$ (Table 2) suggests a major influence of hydraulic sorting processes. A positive correlation between $\mathrm{K}_{2} \mathrm{O}$ and $\mathrm{Al}_{2} \mathrm{O}_{3}$ $(\mathrm{r}=0.975, \mathrm{n}=20$; Table 3$)$ implies that the concentration of the K-bearing minerals has a significant influence on $\mathrm{Al}$ distribution. Its abundance is primarily controlled by clay mineral content $[54,56]$. The lower content of $\mathrm{TiO}_{2}$ (avg. $0.64 \mathrm{wt} \%$ ) suggests more evolved (felsic) materials in the source rocks. But lower $\mathrm{P}_{2} \mathrm{O}_{5}$ content (avg. 0.07 wt \%) suggests a lesser amount of accessory phases such as Apatite and Monazite [10, 21].

\subsection{Principle Component Analysis (PCA)}

The singular value decomposition of the centered log-ratio transformed data was performed for the PCA of these sediments. The extracted principal components can be seen as latent variables that best explain the variance of multivariate data. Table 3 and Figure 4 illustrate the result of the first three principal components graphically. Collectively, the cumulative proportion of the first three principal components account for $77.36 \%$ of the total variance of the geochemical data (Table 3).

Principal component 1 ( $\mathrm{PC}-1)$ shows positive loadings with elements (e.g. $\mathrm{Al}_{2} \mathrm{O}_{3}, \mathrm{TiO}_{2}, \mathrm{~K}_{2} \mathrm{O}, \mathrm{Fe}_{2} \mathrm{O}_{3}, \mathrm{MgO}, \mathrm{Zr}, \mathrm{Zn}$, $\mathrm{Rb}$, and $\mathrm{V}$ ) suggesting positive correlations between $\mathrm{PC}-1$ and these elements (Table 3, Figure 4). Generally, these elements are enriched due to weathering of pre-existing felsic to intermediate igneous rocks and the highest negative loadings are found due to loss of silicate $\left(\mathrm{SiO}_{2}\right)$ during weathering and recycling of sediments [57-59]. Positive loadings of $\mathrm{Al}_{2} \mathrm{O}_{3}$ and negative loading of $\mathrm{SiO}_{2}$ in $\mathrm{PC}-1$ may be related to a de-silicification of alumino-silicates $[6,60]$.

Table 1. Major (in weight percentage) and some minor element (in ppm) abundance Miocene Sediment of Bandarban Anticline.

\begin{tabular}{|c|c|c|c|c|c|c|c|c|c|c|c|c|c|c|c|c|c|c|c|c|}
\hline \multirow{2}{*}{$\begin{array}{l}\text { Sam. } \\
\text { No. } \\
\end{array}$} & \multicolumn{10}{|c|}{ Major element (in weight percent) } & \multicolumn{10}{|c|}{ Minor element (in ppm) } \\
\hline & $\mathrm{SiO}_{2}$ & $\mathbf{A l}_{2} \mathbf{O}_{3}$ & $\mathrm{TiO}_{2}$ & $\mathrm{Fe}_{2} \mathrm{O}_{3}$ & MnO & $\mathrm{CaO}$ & MgO & $\mathrm{Na}_{2} \mathrm{O}$ & $\mathbf{K}_{2} \mathrm{O}$ & $\mathbf{P}_{2} \mathbf{O}_{5}$ & $\mathbf{B a}$ & $\mathbf{N i}$ & $\mathrm{Cu}$ & $\mathbf{Z n}$ & $\mathrm{Cr}$ & $\mathrm{Sr}$ & $\mathbf{V}$ & $\mathbf{R b}$ & $\mathbf{Z r}$ & $\mathbf{G a}$ \\
\hline SS1 & 77.2 & 11 & 0.37 & 4.45 & 0.06 & 1.1 & 1.13 & 1.41 & 2.54 & 0.09 & 375 & 63 & 30 & 33 & 137 & 71 & 75 & 90 & 100 & 18 \\
\hline SS2 & 72.2 & 14.2 & 0.5 & 4.48 & 0.06 & 1.06 & 1.74 & 1.69 & 3.3 & 0.16 & 292 & 55 & 28 & 51 & 105 & 93 & 93 & 114 & 55 & 17 \\
\hline SS3 & 64.8 & 21.2 & 0.82 & 5.41 & 0.05 & 0.72 & 1.68 & 0.70 & 4.07 & 0.14 & 360 & 76 & 52 & 85 & 63 & 130 & 128 & 170 & 130 & 9 \\
\hline SS4 & 74.4 & 15.14 & 0.52 & 4.63 & 0.06 & 0.34 & 1.06 & 0.51 & 2.74 & 0.1 & 342 & 85 & 29 & 47 & 122 & 102 & 102 & 123 & 125 & 10 \\
\hline SS5 & 64.9 & 19.2 & 0.73 & 6.47 & 0.1 & 0.84 & 1.93 & 1.14 & 3.9 & 0.24 & 573 & 67 & 38 & 80 & 63 & 122 & 128 & 152 & 90 & 21 \\
\hline SS6 & 77.2 & 11.7 & 0.47 & 4.35 & 0.08 & 0.84 & 0.86 & 1.18 & 2.66 & 0.12 & 487 & 58 & 26 & 35 & 127 & 80 & 78 & 96 & 75 & 22 \\
\hline SS7 & 77.4 & 12.3 & 0.41 & 4.41 & 0.06 & 0.36 & 0.88 & 0.64 & 2.82 & 0.09 & 373 & 62 & 30 & 48 & 114 & 73 & 82 & 100 & 88 & 14 \\
\hline SS8 & 70.8 & 15.4 & 0.53 & 5.61 & 0.06 & 0.7 & 1.73 & 1.01 & 3.5 & 0.15 & 486 & 63 & 33 & 65 & 92 & 95 & 103 & 128 & 98 & 26 \\
\hline SS9 & 67.2 & 17.5 & 0.72 & 6.29 & 0.09 & 0.88 & 1.98 & 1.00 & 3.65 & 0.19 & 363 & 68 & 43 & 79 & 81 & 117 & 115 & 135 & 105 & 18 \\
\hline SS10 & 53.6 & 8.44 & 0.39 & 4.67 & 0.11 & 9.90 & 1.22 & 0.91 & 2.21 & 0.09 & 456 & 54 & 34 & 47 & 99 & 59 & 70 & 75 & 75 & 12 \\
\hline Sh1 & 64.2 & 18.4 & 0.61 & 6.02 & 0.11 & 1.56 & 2.76 & 1.57 & 3.9 & 0.25 & 477 & 63 & 45 & 90 & 169 & 95 & 170 & 169 & 125 & 25 \\
\hline Sh2 & 60 & 21.7 & 0.88 & 7.55 & 0.06 & 0.79 & 3.16 & 0.84 & 4.44 & 0.14 & 448 & 95 & 54 & 106 & 140 & 105 & 205 & 190 & 130 & 18 \\
\hline Sh3 & 64.5 & 18.8 & 0.68 & 5.77 & 0.1 & 1.35 & 2.65 & 1.48 & 3.93 & 0.2 & 534 & 61 & 38 & 76 & 134 & 88 & 185 & 178 & 128 & 23 \\
\hline Sh4 & 59.8 & 21.7 & 0.85 & 6.92 & 0.12 & 1.24 & 3.02 & 1.19 & 4.49 & 0.19 & 462 & 68 & 44 & 97 & 73 & 103 & 203 & 195 & 135 & 24 \\
\hline Sh5 & 60.1 & 21.7 & 0.76 & 6.9 & 0.12 & 1.32 & 2.78 & 1.17 & 4.5 & 0.21 & 422 & 82 & 57 & 99 & 99 & 107 & 198 & 175 & 148 & 35 \\
\hline Sh6 & 61.5 & 15.2 & 0.66 & 4.9 & 0.28 & 9.96 & 2.09 & 1.36 & 3.32 & 0.24 & 583 & 74 & 45 & 65 & 201 & 98 & 158 & 136 & 105 & 38 \\
\hline Sh7 & 64.4 & 20.1 & 0.76 & 5.86 & 0.06 & 0.94 & 2.1 & 0.97 & 4.08 & 0.17 & 577 & 95 & 54 & 99 & 180 & 115 & 196 & 178 & 128 & 30 \\
\hline $\mathrm{Sh} 8$ & 67.6 & 18.9 & 0.74 & 4.17 & 0.05 & 0.92 & 1.64 & 1.30 & 3.88 & 0.16 & 501 & 64 & 38 & 70 & 232 & 95 & 186 & 168 & 120 & 28 \\
\hline Sh9 & 60.8 & 21.9 & 0.83 & 6.21 & 0.06 & 1.1 & 3.08 & 1.01 & 4.46 & 0.16 & 392 & 87 & 50 & 95 & 62 & 103 & 208 & 188 & 149 & 20 \\
\hline Sh10 & 65.5 & 17.9 & 0.73 & 6.01 & 0.07 & 1.26 & 2.97 & 1.20 & 3.64 & 0.17 & 307 & 85 & 46 & 61 & 195 & 102 & 183 & 158 & 95 & 16 \\
\hline
\end{tabular}


Table 2. Values of Pearson's coefficient of correlation of the Miocene Sediments of Bandarban Anticline.

\begin{tabular}{|c|c|c|c|c|c|c|c|c|c|c|c|c|c|c|c|c|c|c|c|c|}
\hline & $\mathrm{SiO}_{2}$ & $\mathrm{Al}_{2} \mathrm{O}_{3}$ & $\mathrm{TiO}_{2}$ & $\mathrm{Fe}_{2} \mathrm{O}_{3}$ & $\mathrm{MnO}$ & $\mathrm{CaO}$ & $\mathrm{MgO}$ & $\mathrm{Na}_{2} \mathrm{O}$ & $\mathrm{K}_{2} \mathrm{O}$ & $\mathrm{P}_{2} \mathrm{O}_{5}$ & $B a$ & $\mathrm{Ni}$ & $\mathrm{Cu}$ & $Z n$ & $\mathrm{Cr}$ & $S r$ & $V$ & $R \boldsymbol{b}$ & $Z r$ & $G a$ \\
\hline $\mathrm{SiO}_{2}$ & 1 & & & & & & & & & & & & & & & & & & & \\
\hline $\mathrm{Al}_{2} \mathrm{O}_{3}$ & -0.458 & 1 & & & & & & & & & & & & & & & & & & \\
\hline $\mathrm{TiO}_{2}$ & -0.575 & 0.949 & 1 & & & & & & & & & & & & & & & & & \\
\hline $\mathrm{Fe}_{2} \mathrm{O}_{3}$ & -0.593 & 0.763 & 0.752 & 1 & & & & & & & & & & & & & & & & \\
\hline $\mathrm{MnO}$ & -0.389 & -0.061 & 0.045 & 0.063 & 1 & & & & & & & & & & & & & & & \\
\hline $\mathrm{CaO}$ & -0.517 & -0.508 & -0.342 & -0.231 & 0.405 & 1 & & & & & & & & & & & & & & \\
\hline $\mathrm{MgO}$ & -0.655 & 0.785 & 0.778 & 0.835 & 0.174 & -0.195 & 1 & & & & & & & & & & & & & \\
\hline $\mathrm{K}_{2} \mathrm{O}$ & -0.509 & 0.975 & 0.924 & 0.794 & -0.013 & -0.459 & 0.838 & 0.106 & 1 & & & & & & & & & & & \\
\hline $\mathrm{P}_{2} \mathrm{O}_{5}$ & -0.433 & 0.564 & 0.539 & 0.518 & 0.553 & -0.179 & 0.622 & 0.527 & 0.615 & 1 & & & & & & & & & & \\
\hline $\mathrm{Ba}$ & -0.320 & 0.142 & 0.188 & 0.141 & 0.472 & 0.173 & 0.102 & 0.190 & 0.191 & 0.472 & 1 & & & & & & & & & \\
\hline $\mathrm{Ni}$ & -0.290 & 0.626 & 0.643 & 0.538 & -0.080 & -0.291 & 0.499 & -0.427 & 0.531 & 0.090 & -0.022 & 1 & & & & & & & & \\
\hline $\mathrm{Cu}$ & -0.689 & 0.804 & 0.833 & 0.742 & 0.162 & -0.103 & 0.754 & -0.093 & 0.805 & 0.479 & 0.169 & 0.722 & 1 & & & & & & & \\
\hline $\mathrm{Zn}$ & -0.660 & 0.912 & 0.884 & 0.847 & 0.059 & -0.247 & 0.807 & -0.035 & 0.936 & 0.586 & 0.290 & 0.579 & 0.880 & 1 & & & & & & \\
\hline $\mathrm{Cr}$ & 0.075 & -0.089 & -0.034 & -0.298 & 0.210 & 0.015 & 0.026 & 0.322 & -0.099 & 0.120 & 0.264 & 0.132 & 0.040 & -0.125 & 1 & & & & & \\
\hline V & -0.589 & 0.866 & 0.859 & 0.678 & 0.138 & -0.279 & 0.879 & 0.164 & 0.878 & 0.569 & 0.289 & 0.624 & 0.800 & 0.837 & 0.261 & 0.488 & 1 & & & \\
\hline $\mathrm{Rb}$ & -0.514 & 0.972 & 0.929 & 0.736 & 0.000 & -0.436 & 0.842 & 0.070 & 0.960 & 0.583 & 0.236 & 0.596 & 0.792 & 0.906 & 0.049 & 0.681 & 0.938 & 1 & & \\
\hline $\mathrm{Zr}$ & -0.416 & 0.783 & 0.697 & 0.570 & 0.008 & -0.314 & 0.602 & -0.205 & 0.723 & 0.291 & 0.161 & 0.640 & 0.728 & 0.748 & -0.015 & 0.475 & 0.766 & 0.799 & 1 & \\
\hline $\mathrm{Ga}$ & -0.247 & 0.288 & 0.269 & 0.208 & 0.587 & -0.077 & 0.345 & 0.482 & 0.385 & 0.644 & 0.661 & 0.105 & 0.351 & 0.359 & 0.409 & 0.119 & 0.493 & 0.345 & 0.282 & 1 \\
\hline
\end{tabular}
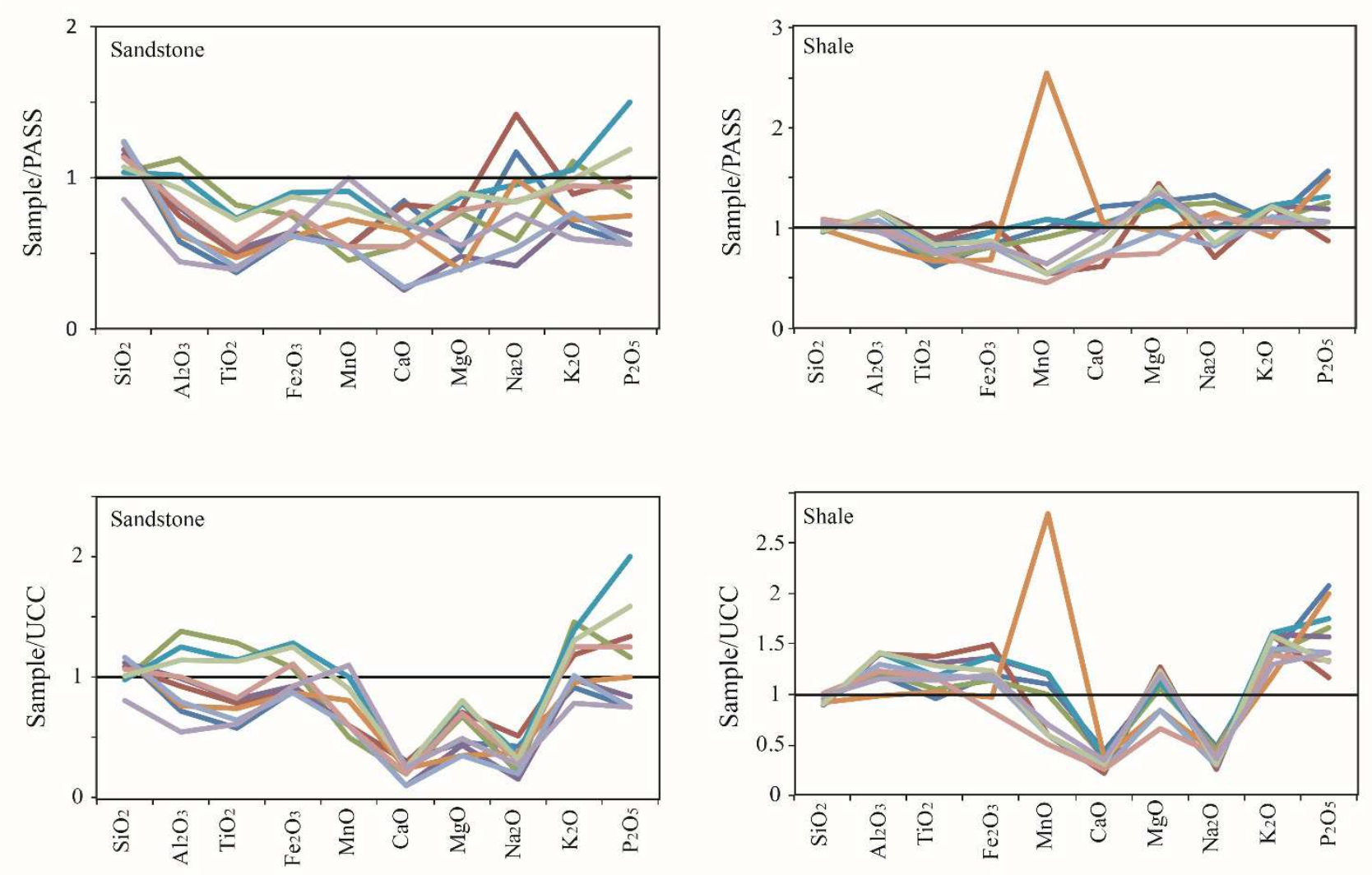

Figure 3. Spider plot of major elements in Miocene sandstones and shales normalized against UCC and PASS (after [48] and [21]).

Principal Component 2 (PC-2) shows the highest loadings with $\mathrm{Na}_{2} \mathrm{O}, \mathrm{CaO}$, and $\mathrm{P}_{2} \mathrm{O}_{5}$ (Table 3; Figure 4). These elements are leached and carried away by groundwater during the weathering process $[61,62]$. The $\mathrm{Al}_{2} \mathrm{O}_{3}, \mathrm{Fe}_{2} \mathrm{O}_{3}$, and $\mathrm{TiO}_{2}$ show nearly zero loadings and $\mathrm{Ni}$ show negative loading (Table 3). The result reflects that $\mathrm{Al}_{2} \mathrm{O}_{3}, \mathrm{Fe}_{2} \mathrm{O}_{3}$, and $\mathrm{TiO}_{2}$ remain in sediment and $\mathrm{Ni}$ are enrich during the weathering process $[61,62]$. The result of $\mathrm{PC}-2$ is consistent with the geochemistry of weathering processes observed in recent weathering profiles [63-67]. Principal component 3 (PC-3) shows the highest loadings with $\mathrm{MnO}, \mathrm{Cr}, \mathrm{Ga}$ and decrease of $\mathrm{Na}_{2} \mathrm{O}, \mathrm{MgO}$ and $\mathrm{K}_{2} \mathrm{O}$, which reflects a change in the mineralogical composition of the sediments due to redox environment of marine sediments during early diagenetic processes $[6,60]$.

Hydraulic sorting processes were an important factor in the fractionation of sand grains and phyllosilicates that affect PC-2. Weathering and hydraulic sorting effects of the 
Miocene sediments govern the geochemical composition of the source rocks. In PC-2, a composite latent variable shows the effects of source-area weathering and hydraulic sorting processes of sediments. Therefore, the present results verify the need to compensate for the effects of weathering and hydraulic sorting processes in order to achieve a robust provenance analysis [68-71].

Table 3. $P C A$ loadings for $P C-1, P C-2$, and $P C-2$.

\begin{tabular}{llll}
\hline \multirow{2}{*}{ Component } & \multicolumn{3}{l}{ Principle Component } \\
\cline { 2 - 4 } & PC-1 & PC-2 & PC-3 \\
\hline $\mathrm{SiO}_{2}$ & -0.587 & -0.332 & -0.110 \\
$\mathrm{Al}_{2} \mathrm{O}_{3}$ & 0.967 & 0.061 & -0.009 \\
$\mathrm{TiO}_{2}$ & 0.950 & 0.050 & 0.050 \\
$\mathrm{Fe}_{2} \mathrm{O}_{3}$ & 0.843 & 0.215 & -0.170 \\
$\mathrm{MnO}$ & -0.018 & 0.485 & 0.554 \\
$\mathrm{CaO}$ & 0.262 & 0.839 & 0.270 \\
$\mathrm{MgO}$ & 0.825 & 0.429 & 0.011 \\
$\mathrm{Na} 2 \mathrm{O}$ & -0.138 & 0.866 & 0.190 \\
$\mathrm{~K}_{2} \mathrm{O}$ & 0.942 & 0.207 & -0.003 \\
$\mathrm{P}_{2} \mathrm{O}_{5}$ & 0.503 & 0.667 & 0.294 \\
$\mathrm{Ba}$ & 0.139 & 0.209 & 0.693 \\
$\mathrm{Ni}$ & 0.732 & -0.462 & 0.189 \\
$\mathrm{Cu}$ & 0.894 & 0.044 & 0.169 \\
$\mathrm{Zn}$ & 0.949 & 0.138 & 0.048 \\
$\mathrm{Cr}$ & -0.110 & -0.010 & 0.777 \\
$\mathrm{Sr}$ & 0.761 & -0.093 & -0.096 \\
$\mathrm{~V}$ & 0.872 & 0.184 & 0.314 \\
$\mathrm{Rb}$ & 0.944 & 0.128 & 0.109 \\
$\mathrm{Zr}$ & 0.809 & -0.145 & 0.174 \\
$\mathrm{Ga}$ & 0.252 & 0.427 & 0.739 \\
$\mathrm{Eigenvalues}$ & 10.57 & 3.52 & 1.39 \\
$\mathrm{Proportion}$ & 52.83 & 17.58 & 6.94 \\
$\mathrm{Cumulative} \mathrm{proportion}$ & 52.83 & 70.42 & 77.36 \\
\hline
\end{tabular}

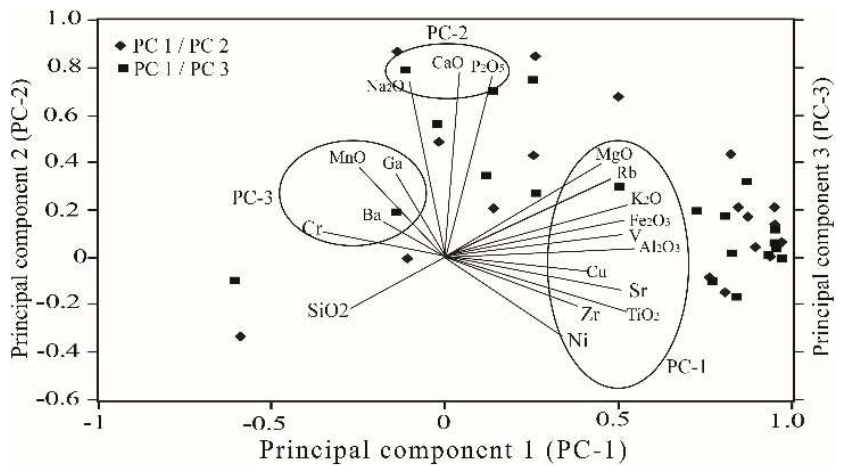

Figure 4. PCA of the studied samples (compositional biplot). Circles indicate the principle loadings of these elements.

\subsection{Weathering and Diagenesis in Source Area}

The PCA of sediments represents the source-area weathering and hydraulic sorting of the original composition of the source rocks [29]. The M, F and W vertices represent the unweathered mafic (M) igneous rocks, unweathered felsic (F) igneous rocks and degree of weathering (W) of parent igneous rocks. Solid and broken lines of Figure 5 represent a compositional linear trend for igneous and weathering profiles of basalt, diorite, and granite respectively [72, 73]. The basalt profiles in Figure 5 is classified into facies 1: fresh rock, facies 2 : intermediately weathered, facies 3 : extensively weathered to facies 4: soil. The proportions of secondary weathering minerals of granite and diorite increase with the increase of weathering and a decrease in bulk density (Figure 5) [29]. Weathering trends on the MFW diagram characterized the relative loss of $\mathrm{Na}_{2} \mathrm{O}$ and $\mathrm{CaO}$, and relative enrichment of $\mathrm{Al}_{2} \mathrm{O}_{3}, \mathrm{Fe}_{2} \mathrm{O}_{3}$, and $\mathrm{P}_{2} \mathrm{O}_{5}$ during weathering. These elementals behavior are usually concordant with $\mathrm{PC}-2$ (Figure 4), which is interpreted as the weathering trend of these sediments. The sediments that are composed of phyllosilicates shows high $\mathrm{W}$ values in the MFW diagram (Figure 5). However, on the MFW diagram, sediments that are composed primarily of weathered residues of source rock depict low $\mathrm{W}$ values and recycled sediments/transported weathered sediments show high $\mathrm{W}$ values, which illustrates a compositional linear trend $[74,75]$ to the $\mathrm{W}$ vertex (Figure 5). Therefore, the compositions of the sediments reflect the weathering or sorting profiles of the source rock compositions rather than the composition of the source rock itself. The weathering trend of the sediments, when extended backward to the $\mathrm{M}-\mathrm{F}$ vertices has an average compositional value, which shows that the sedimentary source is dominant to felsic intermediate-igneous rock (Figure 5). In summary, the backward estimate helps to illustrate the composition of the source area of the sediment.

In addition, the results of grain-size fractionation, weathering, and hydraulic sorting cause considerable modification of sediment compositions [30, 70]; transportation and sorting processes might influence the mineralogically mature sediments [76]. $\mathrm{SiO}_{2} / \mathrm{Al}_{2} \mathrm{O}_{3}$ and $\mathrm{Na}_{2} \mathrm{O} / \mathrm{K}_{2} \mathrm{O}$ ratios are highly susceptible to the fractionation of quartz, albite, and illite during sorting effects and these ratios

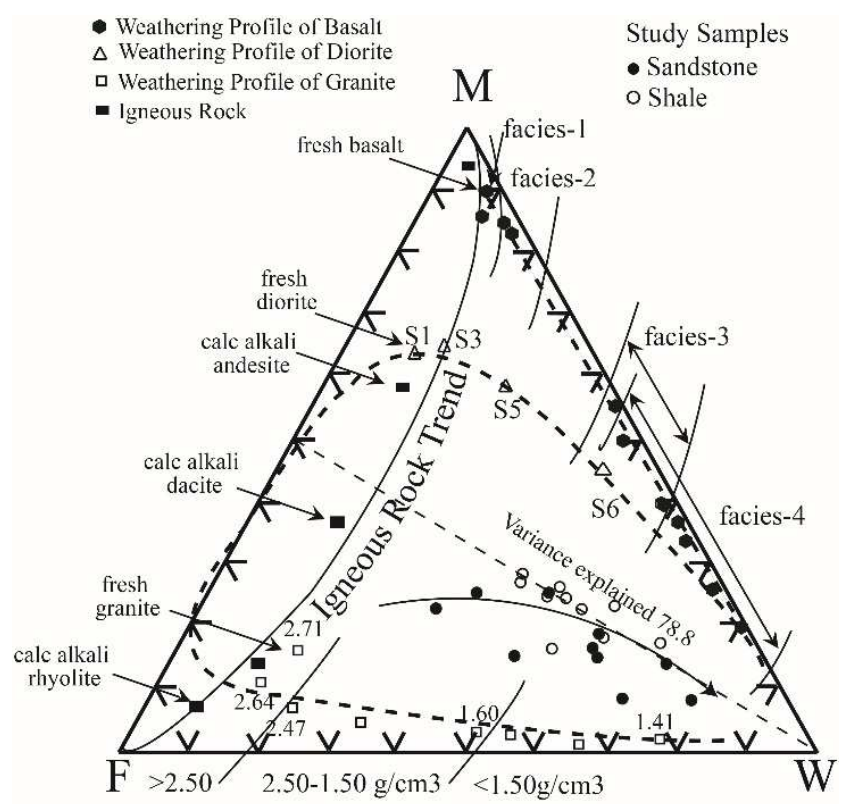

Figure 5. The MFW triangular plots for representative igneous rocks and weathering profiles [29]. See text for a discussion and Appendix Sl. No. 1 for the formula for vertices of the figure.

can be utilized to measure a simple binary response of phyllosilicate and sand-sized particle endmembers during 
hydraulic sorting processes [30]. In Figure 6 dashed lines were calculated contours for $50 \%, 25 \%$ and $15 \%$ matrix compositions for hypothetical sediment composed of quartz, albite, and illite [30]. In this diagram, sediments derived from a recycled sedimentary provenance delineate horizontal trends as shown by Miocene Sediment. On the $\mathrm{SiO}_{2} / \mathrm{Al}_{2} \mathrm{O}_{3}-\mathrm{Na}_{2} \mathrm{O} / \mathrm{K}_{2} \mathrm{O}$ diagram, the sediments plot near the compositional domain of illite that is progressively at a distance from the illitic composition, which reflects the sorting and winnowing effect on phyllosilicates (Figure 6). The initial source compositions determine the slopes in the $\mathrm{SiO}_{2} / \mathrm{Al}_{2} \mathrm{O}_{3}-\mathrm{Na}_{2} \mathrm{O} / \mathrm{K}_{2} \mathrm{O}$ diagram shows that Miocene sediments were sourced primarily from recycled sedimentary rocks [30].

A method for evaluating $\mathrm{K}_{2} \mathrm{O}$ addition using the $\mathrm{A}-\mathrm{CN}-\mathrm{K}$ diagram (Figure 7)-demonstrated by [60] and [77]-is useful for identifying compositional changes of sediments that are related to source rock composition, chemical weathering and diagenesis. In this diagram a represent the $\mathrm{Al}_{2} \mathrm{O}_{3}$, $\mathrm{CN}=\mathrm{CaO}+\mathrm{Na}_{2} \mathrm{O}, \quad \mathrm{K}=\mathrm{K}_{2} \mathrm{O}, \quad \mathrm{CIA}=$ Chemical Index of Alteration, $\mathrm{Ka}=$ Kaolinite, $\mathrm{Gb}=$ Gibbsite, $\mathrm{Chl}=$ Chlorite, $\mathrm{Mu}=$ Muscovite, $\quad \mathrm{Pl}=$ Plagioclase, $\quad \mathrm{Ksp}=\mathrm{K}$-Feldspar, $\mathrm{Sm}=$ Smectite. The stars represent average compositions $\mathrm{B}=$ Basalt, $\mathrm{A}=$ Andesite, $\mathrm{F}=$ Felsic volcanic, $\mathrm{G}=$ Granite [10]; and $\mathrm{UCC}=\mathrm{Upper}$ Continental Crust composition [21]. The solid arrowed line illustrates the trend towards illitemuscovite; the heavy dotted arrowed line is the ideal weathering trend (IWT) showed in this diagram. The sandstones and shale plotted above the line join plagioclase and $\mathrm{K}$-feldspar and extends nearly parallel to the A-CN axis that delineates an ideal weathering trend (Figure 7). This indicates that the removal rate of $\mathrm{Na}$ and $\mathrm{Ca}$ from plagioclase is generally greater than the removal rates of $\mathrm{K}$ from the microcline. The trend inclines towards illite on the $\mathrm{A}-\mathrm{K}$ edge of $\mathrm{A}-\mathrm{CN}-\mathrm{K}$ diagram and does not show any inclination towards the $\mathrm{K}$ apex indicating that the sediments are free from potash metasomatism during diagenesis. The general trends of MFW and $\mathrm{SiO}_{2} / \mathrm{Al}_{2} \mathrm{O}_{3}-\mathrm{Na}_{2} \mathrm{O} / \mathrm{K}_{2} \mathrm{O}$ diagrams show that each formation depicted is closely analogous and the contribution from diagenesis is insignificant as long as $\mathrm{CaO}$ in the carbonate phase is corrected.

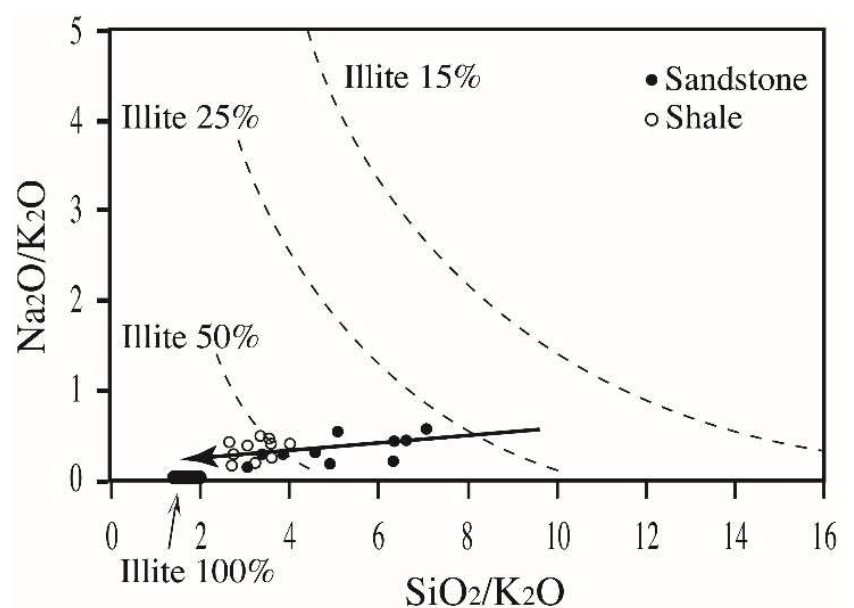

Figure 6. The $\mathrm{SiO}_{2} / \mathrm{Al}_{2} \mathrm{O}_{3}-\mathrm{Na}_{2} \mathrm{O} / \mathrm{K}_{2} \mathrm{O}$ plots of studied sediments illustrating the effect of hydraulic sorting [30].

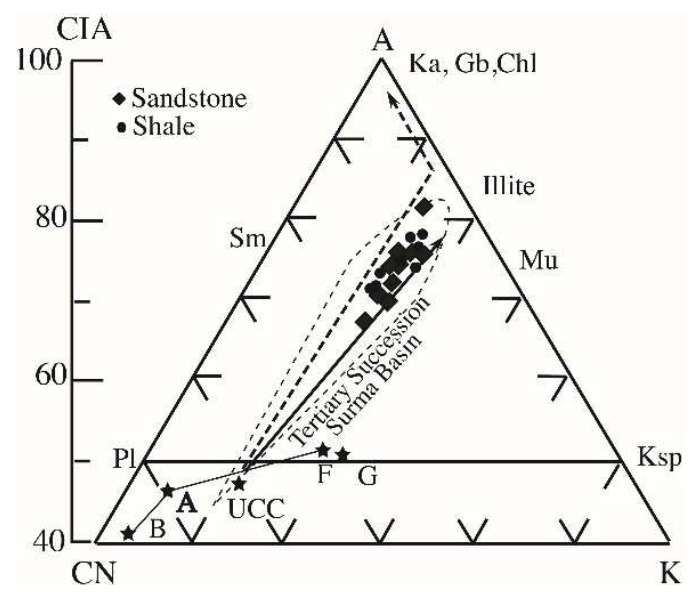

Figure 7. $A-C N-K$ (Nesbitt and Young, 1984) plots for the studied samples and the dotted field area show the Surma Group of sediments in the Surma basin from data in [25]. See text for a discussion of the figure.

\subsection{Tectonic Setting}

On the basis of the geochemical composition, the various tectonic setting discrimination diagrams are used to evaluate the tectonic setting of the region. Discrimination diagrams proposed by [7] and [16] have widely been used to interpret plate tectonics of unknown sedimentary depositional basins using the major-element compositions. Discrimination diagrams proposed by [7] divide tectonic settings as oceanic island arc (OIA), continental island arc (CIA), active continental margin (ACM) and passive continental margin (PM) (Appendix Sl. No. 2; Figure 8a). [16] Differentiate tectonic settings as the OIA, ACM, and PM in their diagram (Figure $8 b)$. Calc-alkaline ternary diagram $\left(\mathrm{CaO}-\mathrm{Na}_{2} \mathrm{O}-\mathrm{K}_{2} \mathrm{O}\right)$ proposed by [32] also differentiates tectonic setting as OIA, CIA, ACM, and PM (Figure 8c). [78] Evaluated the success rate of the major-element-based discrimination diagrams and found a $0 \%-23 \%$ success rate for the [7] diagram and $31.5 \%-52.3 \%$ success rate for the diagram of $[8,16]$. Two new discriminate-function diagrams proposed by [31] have also been used to discriminate tectonic settings as arc (active volcanism), continental rift (extension) and continental collision (compression) for high silica $\left(\mathrm{SiO}_{2}=>63 \%-\leq 95 \%\right)$ and low silica $\left(\mathrm{SiO}_{2}=>35 \%-\leq 63 \%\right)$ sediments (Appendix Sl. No. 3; Figure 9).

Bivariate plots of DF-1 and DF-2 diagram show that most of the samples represent the marginal line of the active continental and passive continental margin fields (Figure 8a). About $60 \%$ of samples represent the passive continental margin and about $40 \%$ fall in the active continental margin field in $\mathrm{SiO}_{2}$ and $\log \left(\mathrm{K}_{2} \mathrm{O} / \mathrm{Na}_{2} \mathrm{O}\right)$ diagram (Figure 8b) and Calc-alkaline ternary diagram $\left(\mathrm{CaO}-\mathrm{Na}_{2} \mathrm{O}-\mathrm{K}_{2} \mathrm{O}\right)$ (Figure $8 \mathrm{c}$ ). Out of Twenty samples the thirteen samples contain high silica and seven samples contain low silica. These samples were used to identify tectonic settings using bivariate plots of DF-1 (Arc-Rift-Col) and DF-2 (Arc-Rift-Col) diagrams [31]. Ten out of thirteen samples of high-silica and four out of seven samples of low-silica are plotted in the collision field (Figure 9). The remaining three samples of silica-rich sediments are plotted in arc whereas three samples are plotted in the 
continental rift field (Figure 9). By comparing all the tectonic discriminant diagrams, it is concluded that the source and depositional areas of the Miocene sediments of the Bandarban Anticline were under the influence of collision (active continental collision, compression) tectonic conditions.

\subsection{Provenance}

The composition of major elements or oxides of siliciclastic sedimentary rocks has been used to identify their source regions and some important methods have been used to characterize the source rocks [13]. In the provenance discrimination diagram of [8], the formulated discriminant

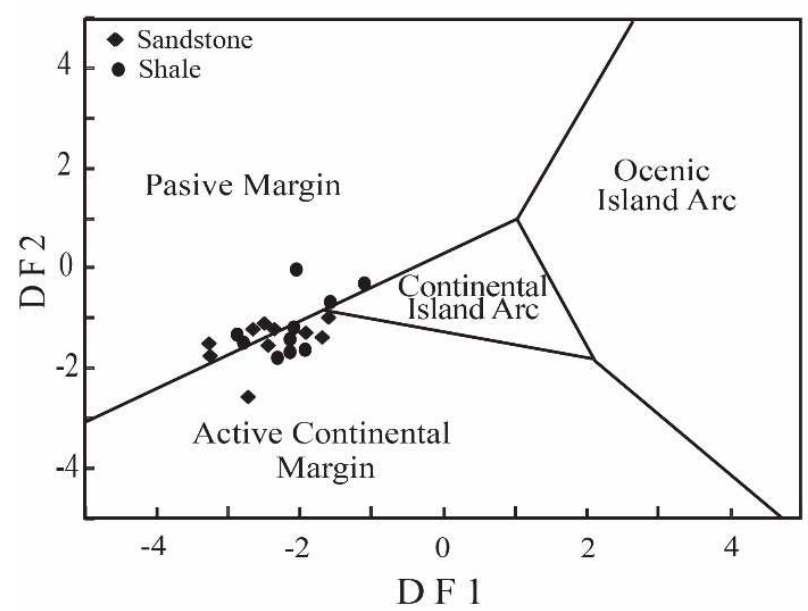

(a) functions (i.e., bivariate) distinguishes major provenance fields, P1 (mafic)-first-cycle basaltic and lesser andesitic detritus; P2 (intermediate)-dominantly andesitic detritus; P3 (felsic)-acid plutonic and volcanic detritus; and P4 (recycled)-mature polycyclic quartzose detritus. In this diagram, most of the samples plotted in mature polycyclic quartzose provenance field and some are scattered in both felsic to intermediate igneous provenance fields (Appendix Sl. No. 4, Figure 10).

The MFW and $\mathrm{SiO}_{2} / \mathrm{Al}_{2} \mathrm{O}_{3}-\mathrm{Na}_{2} \mathrm{O} / \mathrm{K}_{2} \mathrm{O}$ diagrams revealed compositional variations, even after adjusting for the effects of weathering and hydraulic sorting processes (Figures 5 and 6).

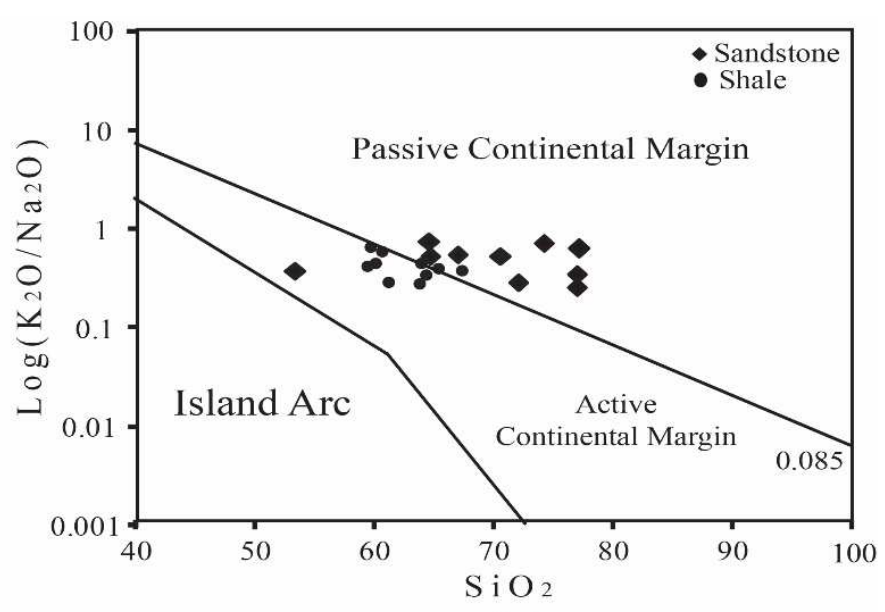

(b)

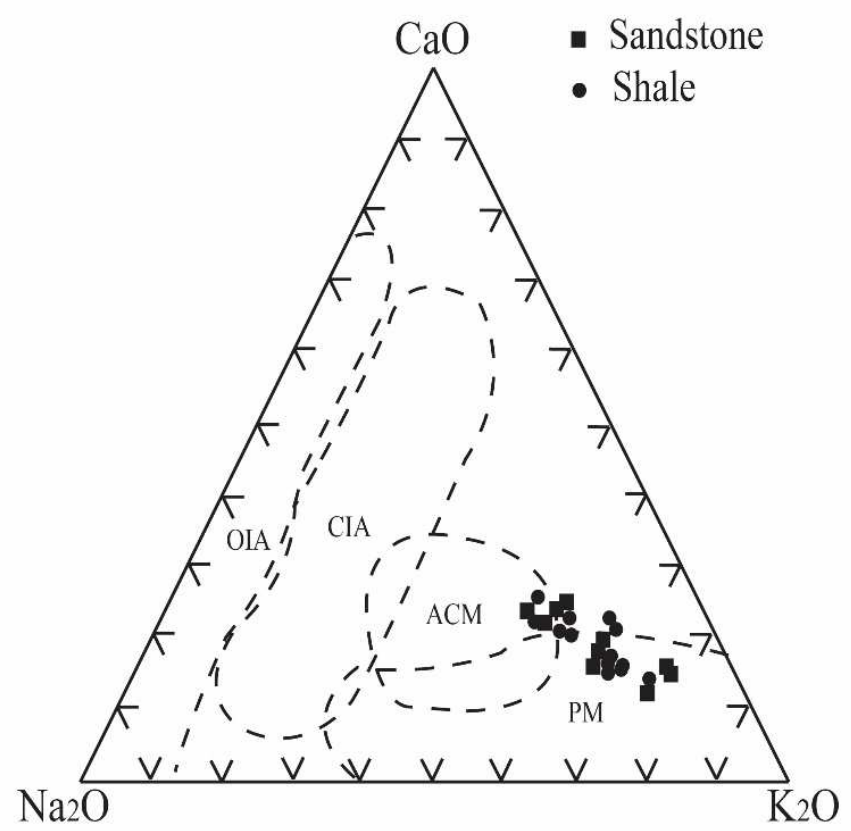

(c)

Figure 8. (a) The tectonic discriminant function diagram [7], (b) $\mathrm{K}_{2} \mathrm{O} / \mathrm{Na}_{2} \mathrm{O}$ vs $\mathrm{SiO}_{2}$ tectonic-setting discrimination diagram [16] and (c) $\mathrm{Na}_{2} \mathrm{O}-\mathrm{CaO}-\mathrm{K}_{2} \mathrm{O}$ ternary plot [32] for studied samples from the Miocene Bhuban and Boka Bil Formation.

In the MFW diagram, The $\mathrm{M}$ and $\mathrm{F}$ vertices represent untethered mafic and felsic igneous rocks and the $\mathrm{W}$ vertex measures the degree of weathering of these parent igneous rocks. The slope and the range of sediment distribution represent that the sediments are extensively weathered/recycled sediment originates from mainly felsic to intermediate rocks. On the biplot (Figure 6) of the $\mathrm{SiO}_{2} / \mathrm{Al}_{2} \mathrm{O}_{3}-\mathrm{Na}_{2} \mathrm{O} / \mathrm{K}_{2} \mathrm{O}$ diagram determined by the initial 
source composition of sediment [30, 79] and the sediment sourced primarily from a recycled sedimentary provenance.

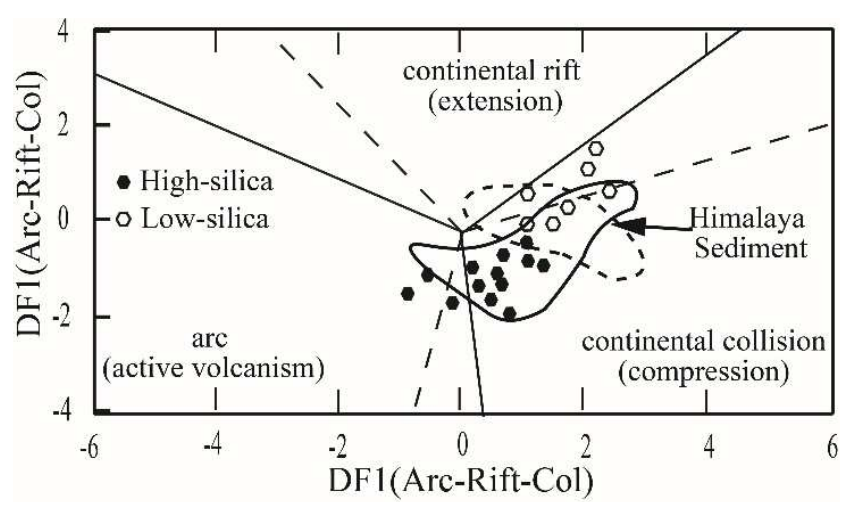

Figure 9. Discriminant-function multi-dimensional diagram [31] for highsilica (solid line) and low-silica (dotted line) clastics for studied samples.

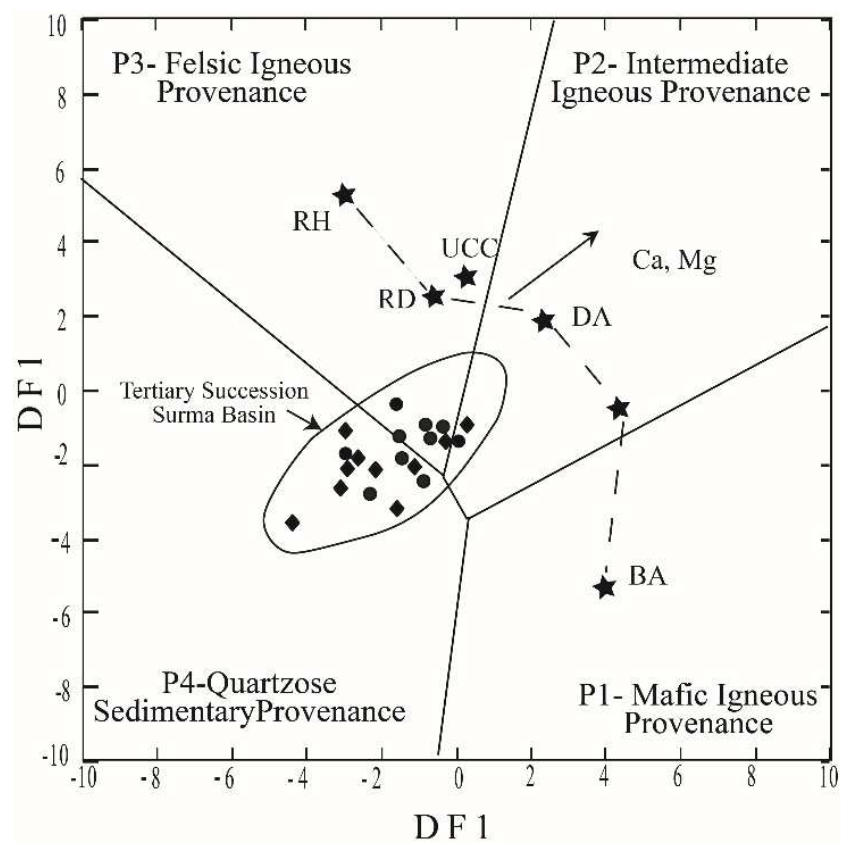

Figure 10. Major element provenance discriminant function plot [8] of studied samples. Fields for Surma Group of Group sediments in Bangladesh from data in [25]. * UCC - average upper continental crust [21]; BA, $A N$, $D A, R D, R H$ - average basalt, andesite, dacite, rhyodacite and rhyolite [8].

\subsection{Sediment Maturity}

The index compositional variation (ICV) can determine the original character and maturity of sediments, as well as the, prevailed climatic conditions [22]. In minerals that are high in weathering intensity and decreases in more stable minerals (less weathered minerals) show the highest tends of the ICV. The ICV decreases more in clay minerals of the montmorillonite group than the kaolinite group [22]. In addition, more mature sediment in the tectonically quiescent or cratonic environment tends to have low ICV values $(<1.0)$ and the first cycle immature sediments deposited in tectonically active settings tends to have more ICV values (> $1)$. For the studied samples, the ICV values of sandstone range from 0.60 to 1.29 (averaging 0.83 ) and shale ranges from 0.63 to 0.88 (averaging 0.78 ). Based on these values, it can be inferred that the sediment is compositionally mature and deposited in the tectonically quiescent environment.

The $\mathrm{K}_{2} \mathrm{O} / \mathrm{Na}_{2} \mathrm{O}$ ratios of sandstone range from 1.81 to 5.81 (averaging 3.47) and shale range from 2.44 to 5.29 (averaging 3.51). These ratios indicate a moderate to high maturity of the sediment [80], which can compare with the ICV values and indicate those of sediments from passive margins, which increase with maturity of rocks [7]. The binary plot of the CIA against ICV for the studied samples (Appendix S1. No. 5; Figure 11) shows that the samples are mature and were derived from both weak and intensively weathered source rocks.

Alternatively, $\mathrm{SiO}_{2} / \mathrm{Al}_{2} \mathrm{O}_{3}$ ratios of siliciclastic rocks are depended on sediment recycling and the weathering process is an indicator of sediment maturity. The average ratios of $\mathrm{SiO}_{2} / \mathrm{Al}_{2} \mathrm{O}_{3}$ in unaltered igneous rocks range from $\sim 3.0$ (basic rocks) to $\sim 5.0$ (acidic rocks) and ratio $>5.0$ indicates progressive maturity sediment [81]. The $\mathrm{SiO}_{2} / \mathrm{Al}_{2} \mathrm{O}_{3}$ ratios of the sandstones vary from 3.06 to 7.02 (averaging 5.11) and shales range from 2.76 to 4.05 (averaging 3.25). The ratios $\mathrm{K}_{2} \mathrm{O} / \mathrm{Na}_{2} \mathrm{O}$ of the sandstones range from 1.81 to 5.81 (averaging 3.47) and shales vary from 2.44 to 5.29 (averaging 3.51). The low values of $\mathrm{K}_{2} \mathrm{O} / \mathrm{Na}_{2} \mathrm{O}$, as well as the high values of $\mathrm{SiO}_{2} / \mathrm{Al}_{2} \mathrm{O}_{3}$, indicate moderate sediment maturity.

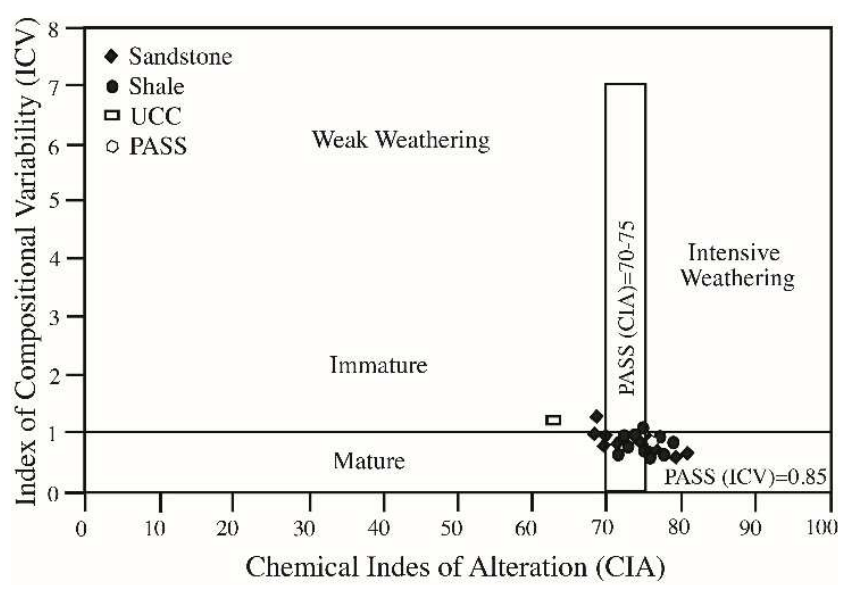

Figure 11. A binary plot of CIA vs ICV of studied samples.

\section{Conclusion}

The geochemical analysis of sediments reflects the provenances, tectonic settings and paleoweathering conditions of sources in the study area. The result of principal component analysis (PCA) of this study shows the enrichment of $\mathrm{Al}_{2} \mathrm{O}_{3}, \mathrm{TiO}_{2}, \mathrm{~K}_{2} \mathrm{O}, \mathrm{Fe}_{2} \mathrm{O}_{3}, \mathrm{MgO}, \mathrm{Zr}, \mathrm{Zn}, \mathrm{Rb}$, and $\mathrm{V}$, and loss of $\mathrm{SiO}_{2}$ during weathering of preexisting source rock ( $\mathrm{PC}-1)$; enrichment of $\mathrm{Na}_{2} \mathrm{O}, \mathrm{CaO}$ and $\mathrm{P}_{2} \mathrm{O}_{5}$ due to leaching and carried by groundwater ( $\mathrm{PC}-2)$; and highest loadings with $\mathrm{MnO}$ and $\mathrm{Cr}$ due to highly redox environment during early diagenetic ( $\mathrm{PC}-3)$. The MFW diagram and $\mathrm{A}-$ $\mathrm{CN}-\mathrm{K}$ diagram show the intense weathering of the source area, and backward trend of MFW and the major elements discriminant diagram shows the sediments are mature 
polycyclic quartzes provenance and originated from dominantly in felsic to intermediate igneous rock. The trend of the $\mathrm{SiO}_{2} / \mathrm{Al}_{2} \mathrm{O}_{3}-\mathrm{Na}_{2} \mathrm{O} / \mathrm{K}_{2} \mathrm{O}$ diagram shows the hydraulic sorting effect and sediments were originated primarily from a recycled sedimentary provenance. The CIA, ICV, and $\mathrm{K}_{2} \mathrm{O} / \mathrm{Na}_{2} \mathrm{O}$ ratios indicate a moderate to high mature sediment and derived from both weak and intensively weathered source rocks. Discriminate diagrams related to clastic sediment revealed the sediment deposit under the influence of collision (active continental margin) and mature weathered sediments derived to depositional basin after collation and upliftment of source area.

\section{Appendix}

1. Formula Used for calculating vertices in Figure 5 [29]

STEP 1

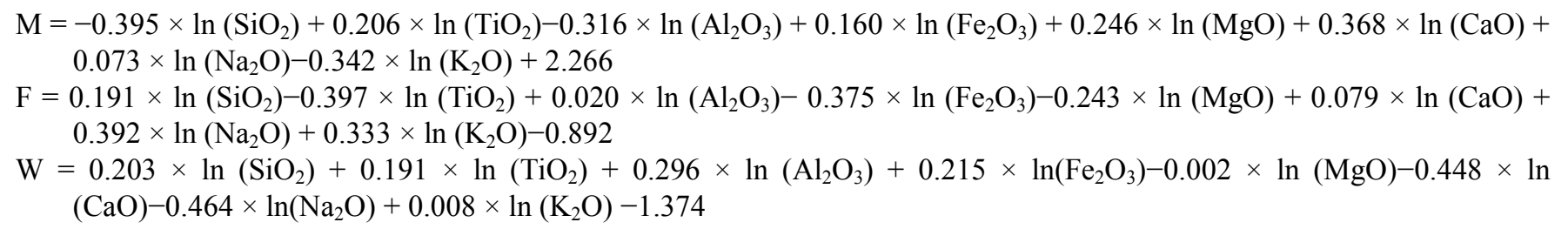

STEP 2

Closure operation: $\mathrm{C} 100[\exp (\mathrm{M}), \exp (\mathrm{F}), \exp (\mathrm{W})]$

2. Formula Used for calculating Discriminant Function of Figure 8-(a) [7]

$\mathrm{DF} 1=\left(-0.0447 \times \mathrm{SiO}_{2}\right)+\left(-0.972 \times \mathrm{TiO}_{2}\right)+\left(0.008 \times \mathrm{Al}_{2} \mathrm{O}_{3}\right)+\left(-0.267 \times \mathrm{Fe}_{2} \mathrm{O}_{3}\right)+(0.208 \times \mathrm{FeO})+(3.082 \times \mathrm{MnO})+(0.140 \times$ $\mathrm{MgO})+(0.195 \times \mathrm{CaO})+\left(0.719 \times \mathrm{Na}_{2} \mathrm{O}\right)+\left(0.032 \times \mathrm{K}_{2} \mathrm{O}\right)+\left(7.510 \times \mathrm{P}_{2} \mathrm{O}_{5}\right)$

$\mathrm{DF} 2=\left(-0.421 \times \mathrm{SiO}_{2}\right)+\left(1.988 \times \mathrm{TiO}_{2}\right)+\left(-0.526 \times \mathrm{Al}_{2} \mathrm{O}_{3}\right)+\left(-0.551 \times \mathrm{Fe}_{2} \mathrm{O}_{3}\right)+(1.610 \times \mathrm{FeO})+(2.720 \times \mathrm{MnO})+(0.881 \times$ $\mathrm{MgO})+(-0.907 \times \mathrm{CaO})+\left(-0.177 \times \mathrm{Na}_{2} \mathrm{O}\right)+\left(-1.840 \times \mathrm{K}_{2} \mathrm{O}\right)+\left(7.244 \times \mathrm{P}_{2} \mathrm{O}_{5}\right)$

3. Formula Used for calculating Discriminant Function of Figure 9 [31]

High-silica $\left[\left(\mathrm{SiO}_{2}\right)_{\text {adj }}=>63 \%-\leq 95 \%\right]$

DF1 ${ }_{\text {Arc-Rift-Col })}=\left(-0.263 \times \ln \left(\mathrm{TiO}_{2} / \mathrm{SiO}_{2}\right) \mathrm{adj}\right)+\left(0.604 \times \ln \left(\mathrm{Al}_{2} \mathrm{O}_{3} / \mathrm{SiO}_{2}\right) \operatorname{adj}\right)+\left(-1.725 \times \ln \left(\mathrm{Fe}_{2} \mathrm{O}_{3} \mathrm{t} / \mathrm{SiO}_{2}\right) \mathrm{adj}\right)+(0.660 \times \ln$ $\left.\left(\mathrm{MnO} / \mathrm{SiO}_{2}\right) \mathrm{adj}\right)+\left(2.191 \times \ln \left(\mathrm{MgO} / \mathrm{SiO}_{2}\right) \mathrm{adj}\right)+\left(0.144 \times \ln \left(\mathrm{CaO} / \mathrm{SiO}_{2}\right) \operatorname{adj}\right)+\left(-1.304 \times \ln \left(\mathrm{Na}_{2} / \mathrm{SiO}_{2}\right) \mathrm{adj}\right)+(0.054 \times$ $\left.\ln \left(\mathrm{K}_{2} \mathrm{O} / \mathrm{SiO}_{2}\right) \mathrm{adj}\right)+\left(-0.330 \times \ln \left(\mathrm{P}_{2} \mathrm{O}_{5} / \mathrm{SiO}_{2}\right) \mathrm{adj}\right)+1.588$

DF2 ${ }_{\text {Arc-Rift-Col })}=\left(-1.196 \times \ln \left(\mathrm{TiO}_{2} / \mathrm{SiO}_{2}\right) \mathrm{adj}\right)+\left(1.064 \times \ln \left(\mathrm{Al}_{2} \mathrm{O}_{3} / \mathrm{SiO}_{2}\right) \operatorname{adj}\right)+\left(-0.303 \times \ln \left(\mathrm{Fe}_{2} \mathrm{O}_{3} \mathrm{t} / \mathrm{SiO}_{2}\right) \mathrm{adj}\right)+(0.436 \times \ln$ $\left.\left(\mathrm{MnO} / \mathrm{SiO}_{2}\right) \mathrm{adj}\right)+\left(0.838 \times \ln \left(\mathrm{MgO} / \mathrm{SiO}_{2}\right) \mathrm{adj}\right)+\left(-0.407 \times \ln \left(\mathrm{CaO} / \mathrm{SiO}_{2}\right) \mathrm{adj}\right)+\left(1.021 \times \ln \left(\mathrm{Na}_{2} / \mathrm{SiO}_{2}\right) \mathrm{adj}\right)+(-1.706 \times$ $\left.\ln \left(\mathrm{K}_{2} \mathrm{O} / \mathrm{SiO}_{2}\right) \mathrm{adj}\right)+\left(-0.126 \times \ln \left(\mathrm{P}_{2} \mathrm{O}_{5} / \mathrm{SiO}_{2}\right) \mathrm{adj}\right)-1.068$

Low-silica $\left[\left(\mathrm{SiO}_{2}\right) \mathrm{adj}=>35 \%-\leq 63 \%\right]$

DF1 ${ }_{(\text {Arc-Rift-Col })}=\left(0.608 \times \ln \left(\mathrm{TiO}_{2} / \mathrm{SiO}_{2}\right)_{\text {adj }}\right)+\left(-1.854 \times \ln \left(\mathrm{Al}_{2} \mathrm{O}_{3} / \mathrm{SiO}_{2}\right)_{\text {adj }}\right)+\left(0.299 \times \ln \left(\mathrm{Fe}_{2} \mathrm{O}_{3}{ }^{\mathrm{t}} / \mathrm{SiO}_{2}\right)_{\mathrm{adj}}\right)+(-0.550 \times \ln$ $\left.\left(\mathrm{MnO} / \mathrm{SiO}_{2}\right)_{\mathrm{adj}}\right)+\left(0.120 \times \ln \left(\mathrm{MgO} / \mathrm{SiO}_{2}\right)_{\mathrm{adj}}\right)+\left(0.194 \times \ln \left(\mathrm{CaO} / \mathrm{SiO}_{2}\right)_{\mathrm{adj}}\right)+\left(-1.510 \times \ln \left(\mathrm{Na}_{2} / \mathrm{SiO}_{2}\right)_{\mathrm{adj}}\right)+(1.941 \times \ln$ $\left.\left(\mathrm{K}_{2} \mathrm{O} / \mathrm{SiO}_{2}\right)_{\mathrm{adj}}\right)+\left(0.003 \times \ln \left(\mathrm{P}_{2} \mathrm{O}_{5} / \mathrm{SiO}_{2}\right)_{\mathrm{adj}}\right)-0.294$

DF2 $\left.{ }_{\text {Arc-Rift-Col) }}=-0.554 \times \ln \left(\mathrm{TiO}_{2} / \mathrm{SiO}_{2}\right)_{\text {adj }}\right)+\left(-0.995 \times \ln \left(\mathrm{Al}_{2} \mathrm{O}_{3} / \mathrm{SiO}_{2}\right)_{\mathrm{adj}}\right)+\left(0.299 \times \ln \left(\mathrm{Fe}_{2} \mathrm{O}_{3}{ }^{\mathrm{t}} / \mathrm{SiO}_{2}\right)_{\mathrm{adj}}\right)+(-1.391 \times \ln$ $\left.\left(\mathrm{MnO} / \mathrm{SiO}_{2}\right)_{\mathrm{adj}}\right)+\left(-1.034 \times \ln \left(\mathrm{MgO} / \mathrm{SiO}_{2}\right)_{\mathrm{adj}}\right)+\left(0.225 \times \ln \left(\mathrm{CaO} / \mathrm{SiO}_{2}\right)_{\mathrm{adj}}\right)+\left(0.713 \times \ln \left(\mathrm{Na}_{2} / \mathrm{SiO}_{2}\right)_{\mathrm{adj}}\right)+(0.330 \times$ $\left.\ln \left(\mathrm{K}_{2} \mathrm{O} / \mathrm{SiO}_{2}\right)_{\text {adj }}\right)+\left(0.637 \times \ln \left(\mathrm{P}_{2} \mathrm{O}_{5} / \mathrm{SiO}_{2}\right)_{\mathrm{adj}}\right)-3.631$

4. Formula Used for calculating Discriminant Function of Figure 10 [8]

DF $1=\left(-1.773 \mathrm{TiO}_{2}\right)+\left(0.607 \mathrm{Al}_{2} \mathrm{O}_{3}\right)+\left(0.760 \mathrm{Fe}_{2} \mathrm{O}_{3}\right)+(-1.500 \mathrm{MgO})+(0.616 \mathrm{CaO})+\left(0.509 \mathrm{Na}_{2} \mathrm{O}\right)+\left(-1.224 \mathrm{~K}_{2} \mathrm{O}\right)+$ $(-9.090)$

DF $2=\left(0.445 \mathrm{TiO}_{2}\right)+\left(0.070 \mathrm{Al}_{2} \mathrm{O}_{3}\right)+\left(-0.250 \mathrm{Fe}_{2} \mathrm{O}_{3}\right)+(-1.142 \mathrm{MgO})+(0.438 \mathrm{CaO})+\left(1.475 \mathrm{Na}_{2} \mathrm{O}\right)+\left(-1.426 \mathrm{~K}_{2} \mathrm{O}\right)+(-$ $6.861)$.

5. Formula Used for calculating ICV and CIA in Figure 11.

$\mathrm{ICV}=\left(\mathrm{Fe}_{2} \mathrm{O}_{3}+\mathrm{K}_{2} \mathrm{O}+\mathrm{Na}_{2} \mathrm{O}+\mathrm{CaO}+\mathrm{MgO}+\mathrm{MnO}\right) / \mathrm{Al}_{2} \mathrm{O}_{3}$ [22]

$\mathrm{CIA}=\left[\mathrm{Al}_{2} \mathrm{O}_{3} /\left(\mathrm{Al}_{2} \mathrm{O}_{3}+\mathrm{CaO} *+\mathrm{Na}_{2} \mathrm{O}+\mathrm{K}_{2} \mathrm{O}\right)\right] \times 100[5]$

\section{Acknowledgements}

The authors would like to thank the Director, Institute of Mining, Mineralogy and Metallurgy IMMM, Joypurhat, Bangladesh for the cordial support for the necessary equipment for geochemical and Atomic Absorption
Spectrometry (AAS) analysis in their laboratory during this research. We also indebted to Prof. Koichi Hoyanagi of the Dept. of Geology of Shinshu University, Japan; Prof. Dr. Md. Sultan-Ul-Islam and Prof. Dr. Ismail Hossain of the Department of Geology and Mining, University of Rajshahi, Bangladesh for the constructive discussion ns suggestion during writing this manuscript. 


\section{References}

[1] Hayashi, K., Fujisawa, H., Holland, H., Ohmoto, H. (1997) Geochemistry of $\sim 1.9 \mathrm{Ga}$ sedimentary rock from northern Labrador Canada. Geochemica et cosmochimica Acta, 61 (19): 4115-4137. DOI: 10.1016/S0016-7037(97)00214-7.

[2] Bookhagen, B., Thiede, R. C., Strecker, M. R. (2005) Late Quaternary intensified monsoon phases control landscape evolution in northwest Himalaya. Geology 33 (2): 149-152. https://doi.org/10.1130/G20982.1.

[3] Singh, A., Debajyoti, P., Sinha, R., Thomsen, K. J., Gupta, S. (2016) Eochemistry of Buried river sediment from Ghaggar Plains NW India: multi-proxy records of variations in provenance, paleoclimate and paleovegetation patterns in the Late Quaternary. Palaeogeography Palaeoclimatology Palaeoecology, 449: 85-100. https://doi.org/10.1016/j.palaeo.2016.02.012.

[4] Dickinson, W. R., Beard, L. S., Brakenridge, G. R., Erjavec, J. L., Ferguson, R. C., Inman, K. F., Knepp, R. A., Lindberg, F. A., Ryberg, P. T. (1983) Provenance of North American Phanerozoic sandstones in relation to tectonic setting: Geological Society of America Bulletin, 94: 222235. Doi: 10.1130/00167606(1983)94<222:PONAPS >2.0.CO;2.

[5] Nesbitt, H. W., Young, G. M. (1982) Early Proterozoic climates and plate motions inferred from major element chemistry of lutites: Nature, 299: 715-717.

[6] Nesbitt, H. W. and Young, G. M. (1984) Prediction of some weathering trends of plutonic and volcanic rocks based on thermodynamic and kinetic considerations. Geochim. Cosmochim. Acta, 48: 1523-1534. https://doi.org/10.1016/0016-7037(84)90408-3.

[7] Bhatia, M. R. (1983) Plate tectonics and geochemical composition of sandstones. Journal of Geology, 91: 611-627. https://doi.org/10.1086/628815.

[8] Roser, B. P., Korsch, R. J. (1988) Provenance signatures of sandstone-mudstone suites determined using discriminant function analysis of major-element data. Chemical Geology, 67: 119-139. https://doi.org/10.1016/0009-2541(88)90010-1.

[9] McCann, T. (1991) Petrological and Geochemical determinations of provenance in southern Welsh Basin. In: A. C. Morton, S. P., Todd and P. D. W. Haughton (editors), Developments in Sedimentary provenance. Geological Socity Special Publication, 57: 215-230.

[10] Condie K. C. (1993) Chemical composition and evolution of the upper continental crust: Contrasting results from surface samples and shales, Journal of Chemical Geology. 104: 1-37. https://doi.org/10.1016/0009-2541(93)90140-E.

[11] McLennan, S. M., Hemming, S., McDaniel, D. K., Hanson, G. N. (1993) Geochemical approaches to sedimentation, provenance and tectonics, in Johnsson, M.J., Basu, A. (eds.): Geological Society of America, Special Papers 285: 21-40. http://dx.doi.org/10.1130/SPE284-p21.

[12] Nesbitt, H. W. and Young, G. M. (1996) Petrogenesis of sediments in the absence of chemical weathering: Effects of abrasion and sorting on bulk composition and mineralogy. Sedimentology, 43: 341-358.
[13] Cullers, R. L. (2000) The geochemistry of shales, siltstones and sandstones of Pennsylvanian-Permian age, Colorado, USA: implications for provenance and metamorphic studies: Lithos, 51: 181-203. https://doi.org/10.1016/S00244937(99)00063-8.

[14] Dickinson, W. R., Suczek, C. A. (1979) Plate tectonics and sandstone compositions: American Association of Petroleum Geologist, 63: 2164-2182.

[15] Bhatia, M. R., Crook, K. A. W. (1986) Trace element characteristics of greywackes and tectonic setting discrimination of sedimentary basins: Contributions to Mineralogy and Petrology, 92: 181-193. 10.1007/BF00375292.

[16] Roser, B. P., Korsch, R. J. (1986) Determination of tectonic setting of sandstone-mudstone suites using $\mathrm{SiO}_{2}$ content and $\mathrm{K}_{2} \mathrm{O} / \mathrm{Na}_{2} \mathrm{O}$ ratio: Journal of Geology, 94: 635-650. https://doi.org/10.1086/629071.

[17] McLennan SM, Taylor SR, McCulloch MT, Maynard JB (1990). Geochemical and Nd-Sr isotopic composition of deepsea turbidites: crustal evolution and plate tectonic associations. Geochim Cosmochim Ac 54: 2015-2050. DOI: 10.1016/00167037(90)90269-Q.

[18] McCulloch, M. T., Wasserburg G. J. (1978) Sm-Nd and Rb-Sr Chronology of the continental crust formation, Science, 200: 1003-1011, DOI: 10.1126/science.200.4345.1003.

[19] Pettijohn, F. J., Potter, P. E., Siever, R. (1975) Sand and Sandstones: New York, Springer-Verlag. Rollinson, H. R., 1993, Using Geochemical Data: Evaluation, Presentation, Interpretation: United Kingdom, Longman, 352 p.

[20] Harnois, L. (1988) The CIW index: A new chemical index of weathering: Sedimentary Geology, 55: 319-322. https://doi.org/10.1016/0037-0738(88)90137-6.

[21] Taylor, S. R., McLennan, S. M. (1985) The continental crust: its composition and evolution: Oxford, Blackwell, $312 \mathrm{p}$.

[22] Cox, R., Low, D. R., Cullers, R. L. (1995) The influence of sediment recycling and basement composition on evolution of mudrock chemistry in the southwestern United States. Geochim. Cosmochim. Acta, 59 (14): 2919-2940. https://doi.org/10.1016/0016-7037(95)00185-9.

[23] Rahman M. J. J., Suzuki, S. (2007) Geochemistry of sandstone from the Miocene Surma Group, Bengal Basin, Bangladesh: Implication for provenance, Techtonic setting and weathering. Geochemical Journal, 41: 415-428. https://doi.org/10.2343/geochemj.41.415.

[24] Rahman, M. J. J., McCann, T. (2012) Diagenetic history of the Surma Group sandstones (Miocene) in the Surma Basin, Bangladesh Journal of Asian Earth Sciences 45: 65-78. https://doi.org/10.1016/j.jseaes.2011.09.019.

[25] Hossain, H. M. Z., Roser B. P., Kimura J. I. (2010) Petrography and whole-rock geochemistry of the Tertiary Sylhet succession, northeastern Bengal Basin, Bangladesh: Provenance and source area weathering. Journal of Sedimentary Geology. 228: 171-183. DOI: 10.1016/j.sedgeo.2010.04.009.

[26] Roy D. and Roser B. P. (2012) Geochemistry of the Tertiary sequence in the Shahbajpur-1 well, Hatia Trough, Bengal Basin, Bangladesh: Provenance, source weathering and province affinity, Journal of Life and Earth Science. 7: 1-13. http://dx.doi.org/10.3329/jles.v7i0.20115. 
[27] Haque, Md. M. Roy, M. K. (2016) Petrography and Geochemistry of Miocene Sandstone, Bandarban Anticline, Bangladesh: Implication for Provenance and Tectonic Settings. Journal of Life and Earth Sciences, 11: 45-57.

[28] Najman, Y., Allen, R., Willett, E. A. F., Carter, A., Barfod, D., Garzanti, E., Wijbrans, J., Bickle, M. J., Vezzoli, G., Ando, S., Oliver, G., Uddin, M. J. (2012) The record of Himalayan erosion preserved in the sedimentary rocks of the Hatia Trough of the Bengal Basin and the Chittagong Hill Tracts, Bangladesh. Basin Research 24: 499-519. doi: 10.1111/j.1365-2117.2011.00540.x.

[29] Ohta, T., Arai, H. (2007) Statistical empirical index of chemical weathering in igneous rocks: a new tool for evaluating the degree of weathering. Chemical Geology, 240: 280-297. https://doi.org/10.1016/j.chemgeo.2007.02.017.

[30] Ohta, T. (2004) Geochemistry of Jurassic to earliest Cretaceous deposits in the Nagato Basin, SW Japan: implication of factor analysis to sorting effects and provenance signatures. Sedimetary Geology, 171: 159-180. https://doi.org/10.1016/j.sedgeo.2004.05.014.

[31] Verma, S. P., Armstrong-Altrin, J. S. (2013) New multidimensional diagrams for tectonic discrimination of siliciclastic sediments and their application to Precambrian basins, Chemical Geology, doi: 10.1016/j.chemgeo.2013.07.014.

[32] Toulkeridis, T., Clauer, N., Goldstein, S. L., Kröner, A., Reimer, T. and Todt, W. (1999) Characterization, provenance, and tectonic setting of Fig Tree greywackes from the Archaean Barberton Greenstone Belt, South Africa. Journal Sedimentary Geology, 124: 113-129. DOI: 10.1016/S00370738(98)00123-7.

[33] Haque, Md. M., Roy, M. K., Joly, N. S. and Roy. P. J. (2010) Sequences Stratigraphy of the Surma Group of Rocks, Bandarban Anticline, Chittagong Hill Tracts, Bangladesh. International Journal of Engineering and Earth sciences, 3 (3) 341-356.

[34] Lindsay, J., Holliday, D., Hulbert, A. (1991) Sequence stratigraphy and the evolution of the Ganges-Brahmaputra delta complex. American Association of Petroleum Geologists Bulletin 75, 1233-1254.

[35] Dewey, J. F., Cande, S., Pitman, W. (1989) Tectonic evolution of the Indian/Eurasian collision zone. Ecologae Geologicae Helvetiae 82 (3): 717-734.

[36] Beck, R., Burbank, D., Sercombe, W., Riley, G., Barndt, J., Berry, J., Afzal, F., Khan, A., Jurgen, H., Metje, J., Cheema, A., Shafigue, N., Lawrence, R., Asif Khan, M. (1995) Stratigraphic evidence for an early collision between northwest India and Asia. Nature 373: 55-58.

[37] Najman, Y. M. R., Pringle, M. S., Johnson, M. R. W., Robertson, A. H. F. (1997) Laser 40Ar/39Ar dating of single detrital muscovite grains from early foreland-basin sedimentary deposits in India: implications for early Himalayan evolution. Geology 25 (6): 535-538. 10.1130/0091-7613(1997)025<0535:LAADOS >2.3.CO;2.

[38] Curray, J., Emmel, F. J., Moore, D. G., Raitt, R. W. (1982) Structure, Tectonics and Geological History of the North-East Indian Ocean. The Ocean Basins and Margins, The Indian Ocean, 6: 399-450. 10.1007/978-1-4615-8038-6 9.

[39] Steckler M. S., Akhter, S. H., Seeber, L. (2008) Collision of the Ganges-Brahmaputra Delta with the Burma Arc: Implications for earthquake hazard Earth and Planetary Science Letters 273: 367-378. https://doi.org/10.1016/j.eps1.2008.07.009.

[40] Curray, J. (2014) The Bengal Depositional System: From rift to orogeny Marine Geology, 352: 59-69. 10.1016/j.margeo.2014.02.001.

[41] Najman, Y., Bickle, M., BouDagher-Fadel, M., Carter, A., Garzanti, E., Paul, M., Wijbrans, J., Willett, E., Oliver, G., Parrish, R., Akhter, H., Allen, R., Ando, S., Christy, E., Reisberg, L., Vezzoli, G. (2008) The Paleogene record of Himalayan erosion, Bengal Basin, Bangladesh. Earth and Planetary Science Letters 273: 1-14. https://doi.org/10.1016/j.epsl.2008.04.028.

[42] Alam, M., Alam, M. A., Curray, J. R., Chowdhury, M. L., Gani, M. R. (2003) An overview of the sedimentary geology of the Bengal Basin in relation to the regional tectonic framework and basin fill history. Sedimentary Geology, 155: 179-208. https://doi.org/10.1016/S0037-0738(02)00180-X.

[43] Mukherjee, A., Fryar, A. E., Thomas, W. A. 2009. Geologic, geomorphic and hydrologic framework and evolution of the Bengal basin, India and Bangladesh, Journal of Asian Earth Sciences 34: 227-244. doi: 10.1016/j.jseaes.2008.05.011.

[44] Uddin, A., Lundberg, N. (1999) A palaeo-Brahmaputra? Subsurface lithofacies analysis of Miocene deltaic sediments in the Himalayan-Bengal system, Bangladesh. Sedimentary Geology, 123: 239-254. DOI: 10.1111/j.13652117.2011.00540.x.

[45] BAPEX 1995. Petroleum geology of Bangladesh. Core Lab. Rep. 139 pp.

[46] Rahman, M. J. J., Faupl, P., Alam, M. M. (2009) Depositional facies of the subsurface Neogene Surma group in the Sylhet trough of the Bengal Basin, Bangladesh: record of tidal sedimentation. International Journal of Earth Sciences 98: 1971-1980. https://doi.org/10.1007/s00531-008-0347-7.

[47] Johnson, S. Y. and Alam, A. M. N. (1991) Sedimentation and tectonics of the Sylhet trough, Bangladesh. Geological Society of American Bulletin 103: 1513-1527. doi.org/10.1130/00167606(1991)103<1513:SATOTS>2.3.CO;2.

[48] Rollinson, H. R. (1993) Using Geochemical Data: Evaluation, Presentation, Interpretation: United Kingdom, Longman, 352 p.

[49] Bock, B., McLennan S. M., Hanson, G. N. (1998) Geochemistry and provenance of the Middle Ordovician Austin Glen Member (Normanskill Formation) and the Taconian Orogeny in New England. Sedimentology, 45: 635655. https://doi.org/10.1046/j.1365-3091.1998.00168.x.

[50] Madhavaraju, J., Lee, Y. I. (2010) Influence of Deccan volcanism in the sedimentary rocks of Late MaastrichtianDanian age of Cauvery basin South-eastern India: constraints from geochemistry. Current Science, 98: 528-537.

[51] Rudnick R. L., Gao S. (2003) Composition of the continental crust. Treatise of Geochemistry, 3: 1-64. DOI: 10.1016/B0-08043751-6/03016-4.

[52] Bauluz, B., Mayayo, M. J., Fernandez-Nieto, C., GonzalezLopez, J. M. (2000) Geochemistry of Precambrian and Paleozoic siliciclastic rocks from the Iberian Range (NE Spain): implications for source-area weathering, sorting, provenance, and tectonic setting. Chemical Geology, 168: 135-150. https://doi.org/10.1016/S0009-2541(00)00192-3. 
[53] Das, B. K., AL-Mikhlafi, A. S., Kaur, P. (2006) Geochemistry of Mansar Lake sediments, Jammu, India: Implication for source-area weathering, provenance, and tectonic setting: Journal of Asian Earth Sciences, 26, 649-668. DOI: 10.1016/j.jseaes.2005.01.005.

[54] Akarish A. I. M., El-Gohary A. M. (2008) Petrography and geochemistry of lower Paleozoic sandstones, East Sinai, Egypt: implications for provenance and tectonic setting. Journal of African Earth Science 52: 43-54. https://doi.org/10.1016/j.jafrearsci.2008.04.002.

[55] Ahmad, I., Chandra, R. (2013) Geochemistry of loess-paleosol sediments of Kashmir Valley, India, Journal of Asian Earth Sciences Volume 66: 73-89, https://doi.org/10.1016/j.jseaes.2012.12.029.

[56] Jin Z, Li F, Cao J, Wang S, Yu. J. (2006) Geochemistry of Daihai Lake sediments, Inner Mongolia, north China: implications for provenance, sedimentary sorting and catchment weathering. Geomorphology 80: 147-163. DOI: 10.1016/j.geomorph.2006.02.006.

[57] Feng, R. and Kerrich, R. (1990) Geochemistry of fine-grained clastic sediments in the Archean Abitibi greenstone belt, Canada: implications for provenance and tectonic setting. Geochim. Cosmochim. Acta, 54: 1061-1081. https://doi.org/10.1016/0016-7037(90)90439-R.

[58] Garver, J. I., Royce, P. R. and Smick, T. A. (1996) Chromium and nickel in shale of the Taconic Foreland: a case study for the provenance of fine-grained sediments with an ultramafic source. J. Sed. Res., 66: 100-106.

[59] Armstrong-Altrin, J. S., Lee, Y. I., Verma, S. P. and Ramasamy, S. (2004) Geochemistry of sandstones from the upper Mio- cene Kudankulam Formation, southern India: implications for provenance, weathering, and tectonic setting. Journal of Sedimentary Research, 74: 285-297. https://doi.org/10.1306/082803740285.

[60] Nesbitt, H. W. Young, G. M. (1989) Formation and diagenesis of weathering profile: Journal of Geology, 97: 129-147. https://doi.org/10.1086/629290.

[61] Nesbitt, H. W., Markovics, G. and Price, R. G. (1980) Chemical processes affecting alkalis and alkaline earths during con- tinental weathering. Geochim. Cosmochim. Acta, 44: 1659-1666. https://doi.org/10.1016/0016-7037(80)902185.

[62] Railsback, L. B. (2003) An earth scientist's periodic table of the elements and their ions. Geology, 31: 737-740. https://doi.org/10.1130/G19542.1.

[63] Nesbitt, H. W. and Markovics, G. (1997) Weathering of grano- dioritic crust, long-term storage of elements in weathering profiles, and petrogenesis of siliciclastic sediments. Geo- chim. Cosmochim. Acta, 61: 1653-1670. https://doi.org/10.1016/S0016-7037(97)00031-8.

[64] White, A. F., Bullen, T. D., Schulz, M. S., Blum, A. E., Hunting- ton, T. G. and Peters, N. E. (2001) Differential rates of feld- spar weathering in granitic regoliths. Geochim. Cosmochim. Acta, 65: 847-869. https://doi.org/10.1016/S0016-7037(00)00577-9.

[65] Duzgoren-Aydin, N. S., Aydin, A. and Malpas, J. (2002) Reassessment of chemical weathering indices: case study on pyroclastic rocks of Hong Kong. Eng. Geol., 63: 99-119. https://doi.org/10.1016/S0013-7952(01)00073-4.
[66] Girty, G. H., Marsh, J., Meltzner, A., McConnell, J. R., Nygren, D., Nygren, J., Prince, G. M., Randall, K., Johnson, D., Heitman, B. and Nielsen, J. (2003) Assessing changes in elemental mass as a result of chemical weathering of granodiorite in a Mediterranean (hot sum- mer) climate. Journal of Sedimentary Research, 73: 434-443. 10.1306/091802730434.

[67] Turner, B. F., Stallard, R. F. and Brantley, S. L. (2003) Investi- gation of in situ weathering of quartz diorite bedrock in the Rio Lcacos basin, Luquillo Experimental Forest, Puerto Rico. Chem. Geol., 202: 313-341. https://doi.org/10.1016/j.chemgeo.2003.05.001.

[68] Argast, S., Donnelly, T. W. (1987) The chemical discrimi- nation of clastic sedimentary components. Journal of Sedimentary Petrology, 57: 813-823. https://doi.org/10.1306/212F8C6F-2B2411D7-8648000102C1865D.

[69] Johnsson, M. J. (1993) The system controlling the composition of clastic sediments. In: Processes Controlling the Compo- sition of Clastic Sediments (Eds M. J. Johnsson and A. Basu), Geol. Soc. Am. Spec. Pap., 284: 1-19. https://doi.org/10.1130/SPE284-p1.

[70] Nesbitt, H. W., Young, G. M. (1996) Petrogenesis of sediments in the absence of chemical weathering: effects of abrasion and sorting on bulk composition and mineralogy. Sedimentology 43: 341-358.

[71] Nesbitt, H. W., Young, G. M., McLennan, S. M. and Keays, R. R. (1996) Effects of chemical weathering and sorting on the petrogenesis of siliciclastic sediments, with implications for provenance studies. J. Geol., 104: 525-542. https://doi.org/10.1086/629850.

[72] Dekayir, A., El-Maataoui, M. (2002) Mineralogy and geochemistry of supergene alteration of an alkali basalt from the Middle Atlas, Morocco. Journal of African Earth Science, 32: 619-633.

[73] Rudnick, R. L., Tomascak, P. B., Njo, H. B., Gardner, L. R. (2004) Extreme lithium isotopic fractionation during continental weathering revealed in saprolites from South Carolina. Chemical Geology 212: 45-57. https://doi.org/10.1016/j.chemgeo.2004.08.008.

[74] Aitchison, J. (1986) The Statistical Analysis of Compositional Data. Chapman \& Hall, London. 416 pp.

[75] Von Eynatten, H., Barceló-Vidal, C., Pawlowsky-Glahn, V. (2003) Modelling compositional change: the example of chemical weathering of granitoid rocks. Math. Geol. 35: 231251. https://doi.org/10.1023/A:1023835513705.

[76] LaFleche, M. R. and Camire, G. (1996) Geochemistry and provenance of metasedimentary rocks from the Archean Golden Pond sequence (Casa Berardi mining district, Abitibi subprovince). Can. Journal of Earth Science, 33: 676-690. https://doi.org/10.1139/e96-051.

[77] Fedo C. M., Nesbitt H. W., Young G. M. (1995) Unraveling the effects of potassium metasomatism in sedimentary rock sand paleosols, with implications for paleoweathering conditions and provenance, journal of Geology. 23: 921-924. DOI: 10.1130/0091-7613(1995)023<0921:UTEOPM>2.3.CO;2.

[78] Armstrong-Altrin, J. S., Verma, S. P. (2005) Critical evaluation of six tectonic setting discrim-ination diagrams using geochemical data of Neogene sediments from known tectonicsettings. Sedimentary Geology 177: 115-129. doi: 10.1016/j.sedgeo.2005.02.004. 
[79] Ohta, T. (2008) Measuring and adjusting the weathering and hydraulic sorting effects for rigorous provenance analysis of sedimentary rocks: a case study from the Jurassic Ashikita Group, south-west Japan Sedimentology 55: 1687-1701, doi: 10.1111/j.1365-3091.2008.00963.x.

[80] Wronkiewicz, D. J., Condie, K. C. (1987) Geochemistry of Archean shales from the Witwatersrand Supergroup, South Africa: source-area weathering and provenance. Geochim.
Cosmochim. Acta, 51: 2401-2416. https://doi.org/10.1016/0016-7037(87)90293-6.

[81] Roser, B. P., Cooper, R., Nathan, S., Tulloch, A. J. (1996) Reconnaissance sandstone geochemistry, provenance and tectonic setting of the Lower Palaeozoic terranes of the West Coast an Nelson, New Zealand. New Zealand. J. Geol. Geophys., 39:

$1-16$. 